\title{
The lysophosphatidic acid (LPA) and sphingosine-1-phosphate (S1P) receptor gene families: cloning and comparative expression analysis in Xenopus laevis
}

\author{
KARINE MASSÉ\#, JUN-ICHI KYUNO, SURINDER BHAMRA and ELIZABETH A. JONES* \\ Department of Biological Sciences, Warwick University, Coventry, U.K.
}

\begin{abstract}
Sphingosine-1-phosphate (S1P) and lysophosphatidic acid (LPA) are endogenous bioactive lipids which mediate a variety of biological cell responses such as cell proliferation, migration, differentiation and apoptosis. Their actions are mediated by binding to the G-proteincoupled endothelial differentiation gene (Edg) receptor subfamily, referred to as S1P1-5 and LPA15 , and regulate a variety of signalling pathways involved in numerous physiological processes and pathological conditions. Their importance during embryogenesis has been demonstrated by the generation of knock-out mice and specific roles have been assigned to these receptors. However, potential functional redundancy and the lethality of some mutants have complicated functional analysis in these models. Here we report the cloning of the S1P and LPA receptors in Xenopus laevis and tropicalis. Phylogenetic analyses demonstrate the high level of conservation of these receptors between amphibian and other vertebrate species. We have conducted a comparative expression analysis of these receptors during development and in the adult frog, by both RT-PCR and whole mount in situ hybridisation. In particular, we show that S1P1, 2 and 5 display distinct embryonic specific expression patterns, suggesting potentially different developmental roles for these receptors, and therefore for their ligands, during amphibian embryogenesis.
\end{abstract}

KEY WORDS: S1P receptors, LPA receptors, Xenopus, expression pattern, lipidic signalling

\section{Introduction}

Besides their roles as structural components of cell membranes, sphingolipid and lipid phosphate molecules, such as sphingosine-1-phosphate (S1P) and lysophosphatidic acid (LPA), regulate diverse biological processes including cell proliferation, cell growth, cell survival, cell migration and cell morphogenesis (Spiegel and Milstien, 2003). Initially these molecules were identified as intracellular signalling components, but their roles as extracellular factors have now also been demonstrated with the discovery of specific cell membrane bound receptors and the evidence of their secretion by cells such as platelets. These discoveries have widened their potential range of physiological functions.

S1P and LPA can signal through a family of related orphan-Gprotein-coupled receptors (GPCR), known as Endothelial Differentiation Genes (EDG) (Takuwa et al. 2002; Anliker and Chun,
2004). Lipid receptors are coupled to at least three major $G$ protein families $\left(G_{i}, G_{q}, G_{12}\right)$ and their interaction regulates the activity of numerous intracellular messengers through the activation or inhibition of the PLC/IP3/Ca ${ }^{2+}$, adenyl cyclase, MAPK pathways and the small GTPase Rho, Rac and Ras proteins. At least 10 receptors have been identified in mammals, are grouped into two subfamilies depending on their ligands and have been renamed following NC-IUPHAR nomenclature guidelines (Lynch, 2002; Chun et al. 2002). The first subfamily, whose receptors mainly bind S1P as their high affinity ligand, includes S1P1/ EDG1, S1P2/EDG5, S1P3/EDG3, S1P4/EDG6 and S1P5/EDG8

\footnotetext{
Abbreviations used in this paper: edg, endothelial differentiation gene; EST, expressed sequence tag; GPCR, G-protein coupled receptors; LPA, lysophosphatidic acid; RT-PCR, reverse transcription-polymerase chain reaction; S1P, sphingosine-1-phosphate; SPC, sphingosylphosphorylcholine.
}

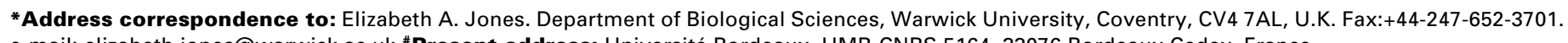
e-mail: elizabeth.jones@warwick.ac.uk \#Present address: Université Bordeaux, UMR-CNRS 5164, 33076 Bordeaux Cedex, France.

Supplementary Material for this paper is available at: http://dx.doi.org/10.1387/ijdb.103068km

Accepted: 11 March 2010. Final author corrected PDF published online: 2 July 2010. Edited by: Roberto Mayor.

ISSN: Online 1696-3547, Print 0214-6282

(C) 2010 UBC Press

Printed in Spain 
(reviewed in Kluk and Hla, 2002; Sanchez and Hla, 2004). Sphingosylphosphorylcholine (SPC) can be a low affinity ligand for these receptors however LPA or ceramide do not compete with S1P for these receptors. The second subfamily includes LPA1/ EDG2, LPA2/EDG4, LPA3/EDG7, LPA4/GPR23/P2Y9, LPA5/ GPR92 and these receptors bind LPA with high affinity (Contos et al. 2000a). LPA1, 2 and 3 are closely related to the S1P receptors whereas the recently cloned LPA4 and 5 are evolutionary more distant and are referred to as non-Edg LPA receptors (Ishii et al. 2009). In adult mammals, LPA1-3 and S1P1-3 are ubiquitously expressed whereas the expression profile of S1P4-5 and LPA4-5 is more restricted (Anliker and Chun, 2004). For example, S1P4 is mostly detected in lymphoid and hematopoietic tissues and S1P5 in the central nervous system, spleen and skin (Sanchez and Hla, 2004). High level of expression of LPA4 is found in ovary whereas LPA5 is highly expressed in small intestine and the dorsal root ganglia (DRG) (Noguchi et al. 2003; Lee et al. 2006).

The broad tissue distribution of these receptors and their potential coupling to several G-protein subfamilies, suggest that S1P and LPA are involved in a multitude of physiological functions, such as angiogenesis, neurogenesis, myelination, wound healing and cholesterol metabolism (Kluk and Hla, 2002; Sengupta et al. 2004). Moreover, crosstalk between bioactive lipids and other signalling pathways has been demonstrated. For example, S1P can activate VEGF (vascular endothelial growth factor) receptors, acting in angiogenesis, cell growth and movement (reviewed in Spiegel and Milstien, 2003). The S1P3 receptor and PDGF (platelet-derived growth factor) receptors can interact and lead to Akt activation (Baudhuin et al. 2004). A variety of evidence identifies emerging roles for these receptors in pathologies, such as cancer, diabetes, atherosclerosis, Alzheimer's disease, Down's syndrome and autoimmune diseases such as Multiple Sclerosis (Mills and Moolenaar, 2003; Sengupta et al. 2004; Brinkmann, 2007). Recent in vivo studies have demonstrated the crucial roles of LPA receptors during breast and colon cancer progression (Liu et al. 2009; Lin et al. 2009). Therefore, LPA and S1P receptors have become targets for developing new drugs for these pathologies (reviewed in Brinkmann, 2007; Zhang et al. 2009).

The specific functions of each LPA and S1P receptor have been elucidated by the generation of knock-out mice. These have demonstrated the pivotal role of lipid pathways during cardiovascular and neuronal development (Osborne and Stainier, 2003; Saba, 2004). To date, single, double or triple null-mice have been reported for most of the receptor genes (with the exclusion of $\angle P A 4$, $\angle P A 5$ and S1PA) and have demonstrated some specific functions for each receptor (reviewed in Brinkmann, 2007; Choi et al. 2008). LPA1-null mice show $50 \%$ perinatal lethality, due to suckling defects, and the survivors exhibited abnormal phenotypes such as craniofacial abnormalities (Contos et al. 2000b). Cortical development was affected in a spontaneous variant of these original knockout mice (Estivill-Torrús et al. 2008). Analysis of the LPA3 mutant mice demonstrates the importance of this receptor in embryo implantation (Ye et al. 2005). Redundant functions for LPA receptors have been suggested since no obvious phenotype can be observed in LPA2-null mice, and LPA1/LPA2 double-null mice showed no additional phenotype to that of LPA1-null mice (Contos et al. 2002). S1P1 null-mice have the most severe phenotype, with death in utero caused by embryonic hemorrhage (Liu et al. 2000). Conditional S1P1 mutants demonstrated a role in maturation of vascular endothelial cells and in lymphocyte egress (Allende et al. 2003, 2004; Matloubian et al. 2004; Kabashima et al. 2006). Despite roles of S1P2 in heart development suggested from the zebrafish mutant "miles apart" (Kupperman et al. 2000), no such phenotype is observed in the S1P2 null-mice (Ishii etal.2002) even though loss of S1P2 induced vascular dysfunction in adult mice (Lorenz et al. 2007). However, the generation of three independent mutant mice strains demonstrated the fundamental role of S1P1 in the maintenance of auditory and vestibular systems since hearing deficiencies resulted in deafness (MacLennan et al. 2006; Kono et al. 2007; Herr et al. 2007). S1P3 null mice displayed no gross phenotype although some S1P-mediated responses were impaired (Ishii et al. 2001). Generation of double and triple mutant mice for these 3 S1P receptors confirmed their redundancy in vivo (Ishii et al. 2002; Kono et al. 2004). Fertile S1P5 knock-out mice confirmed the role of this receptor in the immune system but failed to display any evident neuronal defects despite its influence on oligodendrocyte development (Jaillard et al. 2005; Walzer et al. 2007).

Spatial-temporal concentrations of LPA and S1P are tightly regulated by several enzymes involved in either the anabolism or catabolism of these lysophospholipids (Spiegel and Milstien, 2003; Saba, 2004). The complexity of lipid signalling increases further due to intersections between LPA and S1P metabolism (Saba, 2004). Several members of the nucleotide pyrophosphatase/phosphodiesterase (ENPP) family, a subfamily of ectonucleotidases involved in the regulation of purinergic signalling, catalyse the generation of these bioactive lipids (reviewed in Stefan etal. 2005). ENPP2 or autotaxin is a lysophospholipase D (lysoPLD) which generates LPA from lysophosphatidylcholine (LPC) but also S1P from SPC (reviewed in Moolenar et al. 2004; van Meeteren and Moolenar, 2007). ENPP6 is a choline-specific glycerophosphodiesterase which produces phosphocholine by degrading choline-containing compounds such as LPC and SPC (Sakagami etal.2005) and ENPP7 is the intestine-specific alkaline sphingomyelinase (alk-SMase) which hydrolyses sphingomyelin (SM) into ceramide and sphingosine (Duan, 2006).

The LPA and S1P pathways have been conserved during evolution and their roles demonstrated from yeast to invertebrates and vertebrates even though the Edg receptors have not been identified in invertebrates (Spiegel and Milstien, 2003; Oskouian and Saba, 2004). Due to the complexity of the lipidic pathways and the potential redundancy in vivo of the functions of their diverse components, we opted to analyse their function during development using a simple but very well established vertebrate model, the amphibian Xenopus laevis. We have cloned all the amphibian enpp members and analysed their expression during $X$. laevis development (Massé et al. 2010). The distinct expression profile of enpp2, enpp6 and enpp7suggests specific roles for these genes during embryogenesis and therefore for the lipids generated by their catalytic activity. Here, we report the cloning and characterisation of the 10 edg receptors of the LPA and S1P families in $X$. laevis and $X$. tropicalis. We compare their temporal and spatial expression during development and also their distribution in adult frog tissues. The developmentally restricted and dynamic distributions of these receptors strongly suggest that the LPA and S1P pathways might play important and diverse developmental roles, and together with our previously published work, provide the tools for the functional analysis of 

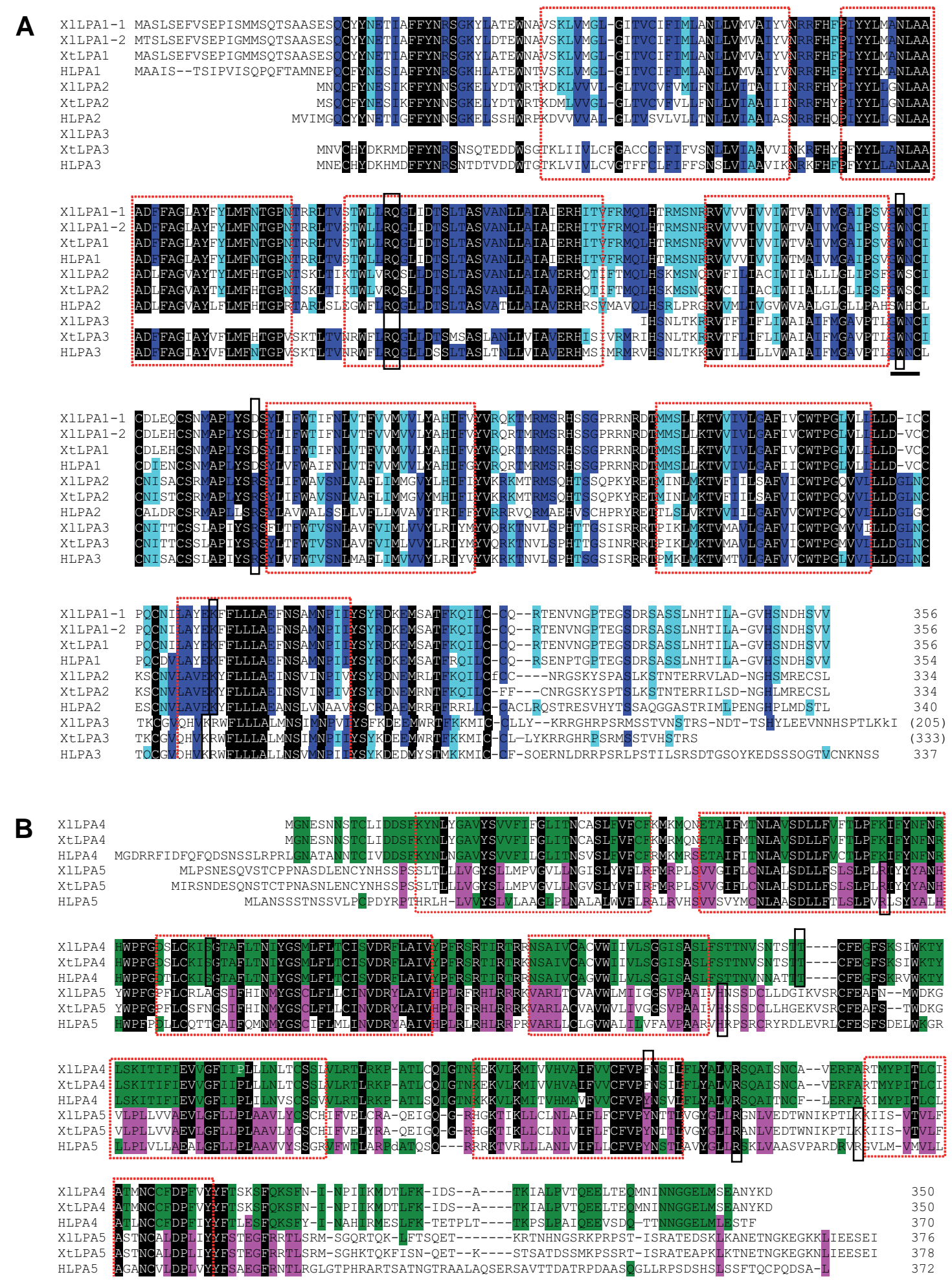

Fig. 1. Protein sequence alignment of Xenopus lysophosphatidic acid (LPA) receptors. Alignment of the LPA1-3 (A) or LPA4-5 (B) proteins was performed using CLUSTALW. The X. laevis (XI) and X. tropicalis (Xt) proteins were aligned with their human orthologs (H). The Genbank accession numbers of the human LPA receptors are given in the legend of Fig. 3. The size of the proteins (AA numbers), complete or incomplete (in bracket) is also given. Spaces in the sequences are indicated by a dash. The 7 transmembrane domains are indicated by a red box. The amino acids involved in LPA binding are highlighted by the boxed regions. (A) Residues conserved in all sequences are indicated by a black background. Residues conserved in at least one group of orthologs are indicated by a light turquoise background. Residues conserved in at least two groups of orthologs are indicated by a dark blue background. The GWNC motif is underlined. (B) Residues conserved either in all sequences or in 5 out of the 6 proteins are indicated by a green background. Residues conserved in LPA4 sequences are indicated by a light grey background. Residues conserved in LPA5 sequences are indicated by a pink background. 
these pathways during development (Massé et al. 2010).

\section{Results}

\section{Cloning of the different receptor genes}

A variety of strategies, as described in Supplementary Table
$1 \mathrm{~A}$, were used in order to clone the different members of $\angle P A$ and S1P gene families. TBLASTN search of the $X$. laevis and tropicalis databases on the NCBI website allowed the identification of full length I.M.A.G.E clones encoding several receptors (Accession numbers given in Supplementary Table 1B). X. laevis LPA1.1 and LPA1.2 and $X$. tropicalis LPA2 sequences have been
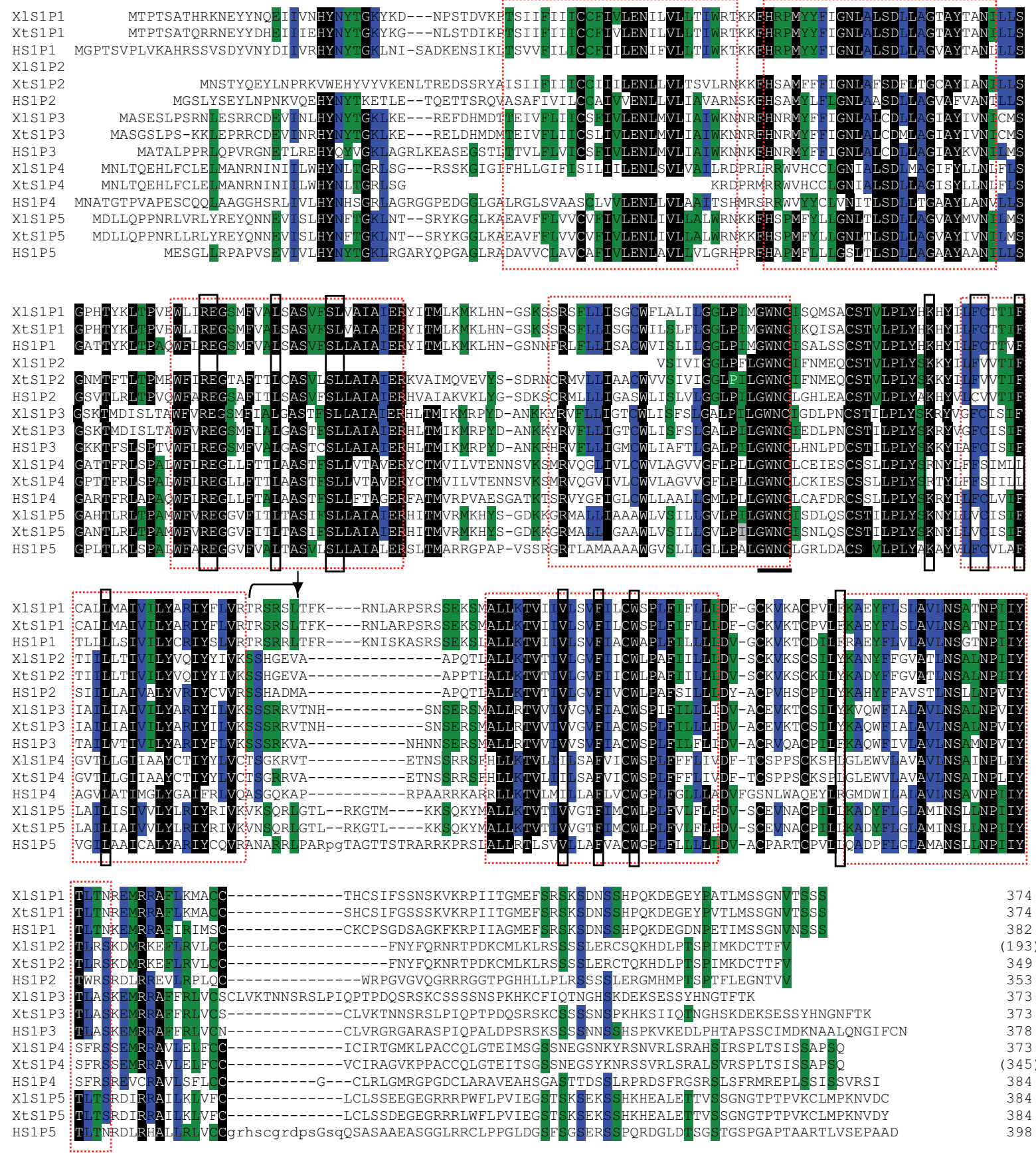

Fig. 2. Protein sequence alignment of Xenopus sphingosine-1-phosphate (S1P) receptors. The $X$. laevis $(X I)$ and $X$. tropicalis $(X t)$ proteins were aligned with their human orthologs (H) using CLUSTALW. Residues conserved either in all sequences or at least four of the five orthologs are indicated by a dark background. Residues conserved in at least three groups of orthologs are indicated by a blue background. Residues conserved in two groups of orthologs are indicated by a green background. The seven potential transmembrane domains (TMs) indicated by a red box. The S1P1 characteristic $(R x R x x T / S)$ motif is indicated by a bracket. The arrow indicates the phosphorylation site by the B/Akt protein kinase. The GWNC motif is underlined. The amino acids involved in the S1P binding are boxed. Spaces in the sequences are indicated by a dash. The Genbank accession numbers of the human S1P receptors are given in the legend of Fig. 3. The size of the proteins (AA numbers), complete or incomplete (in bracket) is also given. 
previously published (Kimura et al. 2001; Lloyd et al. 2005). For the other receptors, $X$. laevis or $X$. tropicalis ESTs were identified and alignments of these sequences were performed to generate the consensus but incomplete sequence of their cDNA. Sequences were also identified by BLAST on the genomic $X$. tropicalis databases (JGI website) and the deduced cDNA sequences corrected by reference to the human sequence according to the Breathnach and Chambon law (Breathnach and Chambon, 1981). When needed, RT-PCRs were performed on $X$. laevis and $X$. tropicalis embryonic and adult tissues to amplify the missing sequences. This work allowed us to obtain the complete protein sequences for all receptors except $X$. laevis and $X$. tropicalis LPA3, $X$. laevisS1P2 and $X$. tropicalisS1P4 (Figs. 1 and 2).

\section{Protein and phylogenetic analysis of the LPA and S1P fami- lies}

The Xenopus sequences of these receptors are highly similar (Figs. 1A,B and 2). The $X$. laevis and $X$. tropicalis orthologs share more than $95 \%$ identity and more than $97 \%$ similarity with the exception of LPA5 ( $88.4 \%$ identity and $92.1 \%$ similarity). The two Xenopus LPA4 orthologs share $99.4 \%$ identity and $100 \%$ similarity. However, the percentage of identity between the different members of these families is less than $60 \%$ in the same species. $X$. laevis LPA1.1 (or LPA1.2) shares $55 \%$ identity with LPA2 but only $20 \%$ identity with LPA4 or LPA5 sequences. $X$. tropicalis LPA3 shares approximately $50 \%$ identity with $X$. tropicalis LPA1 or LPA2 and only approximately $20 \%$ with $X$. tropicalis LPA4 or LPA5. The percentage of identity along the five S1P receptors in $X$. laevis or $X$. tropicalis is higher, between 30 to $50 \%$, with S1P1,
3 and 5 sharing a higher percentage of identity. For example, $X$. laevis S1P1 share $49 \%$ and $49.7 \%$ identity with S1P3 and S1P5 respectively and only $35.3 \%$ with S1P4. $X$. tropicalis S1P1 and S1P2 share $44.7 \%$ identity. The lowest percentage of identity is between $X$. laevis S1P4 and S1P5 proteins (34.2\%).

A phylogenetic analysis of these receptors in Xenopus and other vertebrates was carried out (Fig. 3, Supplementary Fig. 1). Clustering of these sequences demonstrates the clear separation of LPA from S1P proteins (Fig. 3). However, LPA1, 2, 3 are more related to S1P receptors than LPA4 and 5. Indeed, XenopusLPA4 or LPA5 receptors only share approximately $20 \%$ identity with the other LPA and S1P receptors. By contrast, LPA1, 2 and 3 share $30 \%$ identity with the five S1P receptors in Xenopus. Among S1P receptors, S1P1, 3 and 5 are more related to each other than S1P2, with S1P4 appearing the most divergent member. Xenopus S1P4 shares only around 35\% with the other four S1P receptors. Moreover, each member is more related to its orthologs than to the other family members in the same species, suggesting that any function identified in $X$. laevis may well be conserved in other vertebrates. It is worth pointing out that the sequences of human S1P5 and zebrafish LPA2 in the database do not cluster with their orthologs, suggesting a potential divergence of the roles for these receptors during vertebrate evolution. However, a more complete phylogenetic analysis of the S1P5 receptors using the Ensembl database revealed that the Xenopus tropicalis sequence has been annotated as S1P5 protein, ruling out a potential mis-identification of the Xenopus laevis protein.

The percentage of identity between the members of an orthologous group of proteins is very variable; LPA1 is the most conserved receptor and LPA5 and S1P5 the least conserved

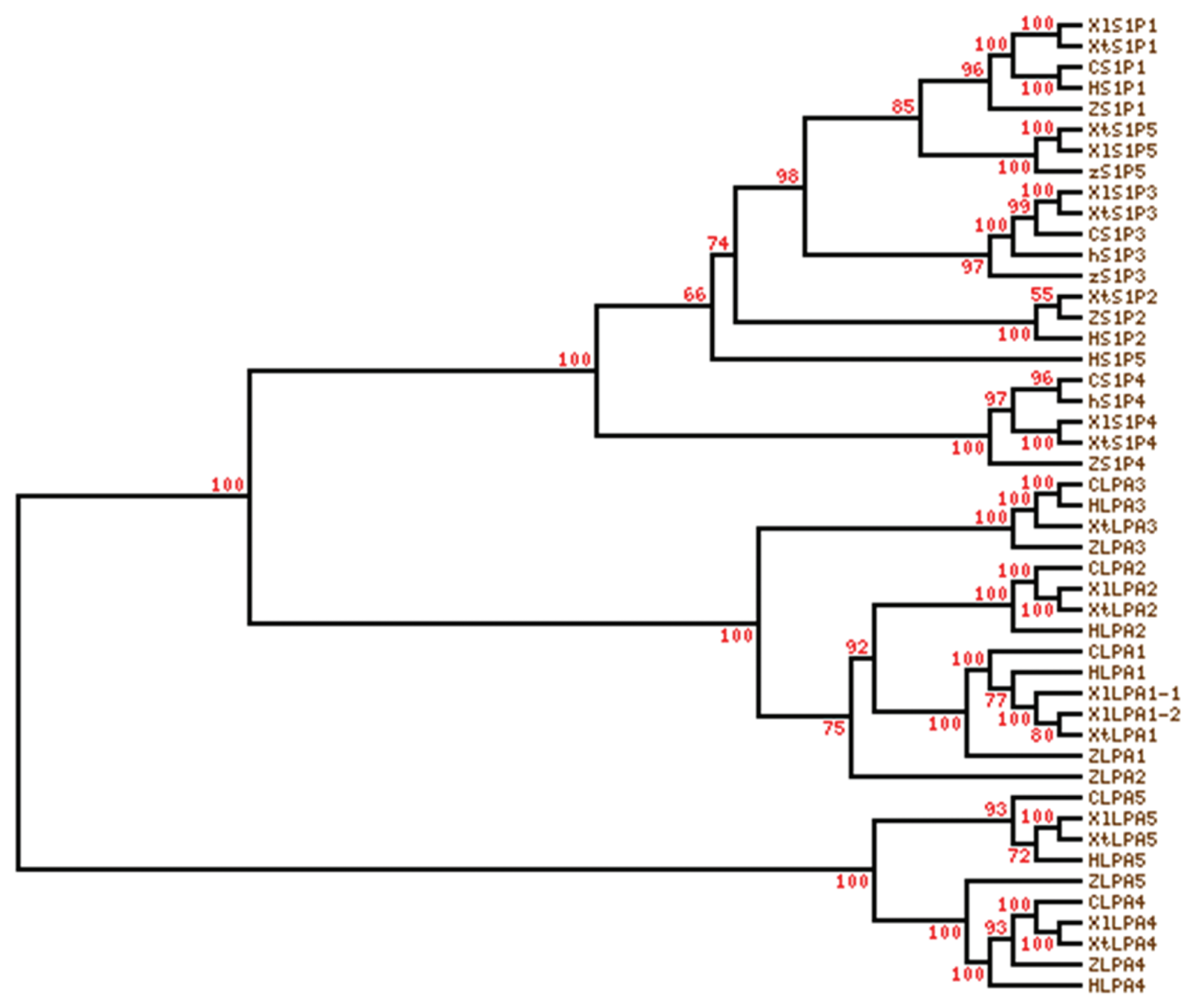

Fig. 3. Phylogenetic conservation of the lipidic receptors. A phylogenetic tree for the LPA and S1P receptors was constructed using the PHYLIP program. A cluster algorithm was used to build the tree. Bootstrap values are indicated at each node of the tree. The Genbank accession numbers of the different receptors are as follows: human LPA1: NP_001392; human LPA2: NP_004711; human LPA3: AAF91291; human LPA4: NP_005287; human LPA5: NP_065133; human S1P1: NP_001391; human S1P2: NP_004221; human S1P3: NP_005217; human S1P4: AAH14940; human S1P5: NP_110387; chick LPA1: ABY60418; chick LPA2: NP_001108553; chick LPA3: ABY60420; chick LPA4: XP_420150; chick LPA5: XP_416504; chick S1P1: XP_001231780; chick S1P3: XP_428818; chick S1P4: NP_001112363; zebrafish Ipa1: NP_001004502; zebrafish Ipa2: NP_001032783; zebrafish Ipa3: XP_694990; zebrafish Ipa4: XP8001334713; zebrafish lpa5: NP_001073524; zebrafish s1p1: NP_571766; zebrafish s1p2: XP_682912; zebrafish s1p3: XP_001345724; zebrafish s1p4: AAH66587; zebrafish s1p5: NP_001007317. The X. laevis LPA3 and S1P2 proteins were excluded since their sequence are incomplete. C: Chick; H: human; XI: X. laevis; Xt: X. tropicalis; Z: Zebrafish. 
members during vertebrate evolution. As shown in Supplementary Fig. 1, the mammalian, fish and amphibian S1P5 receptor sequences have diverged more during evolution than the other S1P members. Xenopus LPA1.1 and LPA1.2 share more than $90 \%$ identity with their mammal and chick orthologs and $85 \%$ with their zebrafish ortholog. Xenopus S1P5 and LPA5 only share 40 to $50 \%$ identity with their orthogs. The other receptors share more than $70 \%$ identity with their orthologs, except LPA2 and S1P2 for which the percentage of identity with the other vertebrate sequences is only around 60\%. Except for S1P2 and S1P5, the zebrafish and Xenopus sequences share the lowest percentage of identity.

\section{Temporal expression of LPA and S1P gene families during development of Xenopus laevis}

The temporal expression of these genes during development was assessed using gene specific primers by RT-PCR as described in Supplementary Table 2 (Fig. 4). The $S 1 P$ receptors are not expressed maternally, with the exception of S1P3 whose expression remains at a constant level during development at all the stages tested, except between stages 27 to 37 . This apparent drop of expression was confirmed in another independent experiment, but its physiological significance remains unknown. If the numbers of cycles is increased, very weak maternal expression can be detected for S1P1 and S1P2. Zygotic expression of S1P1 and S1P2 is detectable weakly at stage 10.5 and their level of expression increases until stage 45. S1P5 expression is also detectable during gastrulation and remains expressed until stage 45 at a similar level. S1P4 is the only family member whose transcripts cannot be detected at any stage in this experiment.

All $\angle P A$ genes, however, are expressed maternally with the exception of $\angle P A 3$. The expression of $\angle P A 1.1, \angle P A 1.2$ and $\angle P A 4$ remains at a similar level from the oocyte to stage 45 , the last stage tested in this study. Maternal expression of $\angle P A 2$ decreases quickly to an almost undetectable level at stage 8 and its zygotic expression is detected from gastrulation throughout development. $\angle P A 5$ expression is the highest before MBT but its zygotic transcripts can be amplified until stage 45. Zygotic expression of $\angle P A 3$ is switched on weakly during neurulation with an increase of expression at stage 37. However, its expression can be weakly detected during gastrulation with an increase of cycle numbers.

\section{Spatial expression of LPA and S1P gene families during development of Xenopus laevis}

The spatial expression of these genes in the embryo was assessed by two different complementary techniques. In situ hybridisation allows the identification of domains of high expression of genes; RT-PCR on the other hand identifies regions of both high and low expression domains in dissected embryos. In situ hybridisation was performed on embryos from stage 6 to stage 40/41 with specific antisense probes (see Supplementary Table 3). Sense probes were used as controls.

Zygotic expression of S1P1, S1P2 and S1P5 genes can be detected by in situ hybridisation and these receptors display distinct and different expression profiles during development (Fig. $5 \mathrm{~A}-\mathrm{C})$. S1P4expression was not analysed by in situhybridisation as its expression was only very weakly detected by RT-PCR. $S 1 P 1$ expression is detected from stage 23 in the nervous system, in the brain and the neural tube as seen on cleared embryos (Fig. $5 \mathrm{Ai}, \mathrm{ii})$. This expression in the nervous system is more intense at stage 27 (Fig. 5-Aiii). Expression in the otic placode can also been observed from this stage. Neural expression can be more precisely observed in the forebrain, midbrain, hindbrain and spinal cord from stage 32 (Fig. 5-Av, vi). Strong expression can be detected in all the rhombomeres of the hindbrain from stage 37
Fig. 4. Temporal expression profile of LPA and S1P families genes. RT-PCR analysis showing expression pattern of the receptor transcripts in Xenopus laevis unfertilised eggs and embryos. Expression of the LPA1.1, LPA1.2, LPA4 and $\mathrm{S} 1 \mathrm{P} 3$ genes is constant during development. Expression of S1P1, 2 and 5 is first detected at stage 10.5 and increases until stage 45 , the latest stage tested whereas the expression of $1 \mathrm{P} 5$ remains at approximately the same level during development. LPA2 is a maternal gene; its zygotic expression is also switched on at stage 10.5 and expressed until stage 45. Expression of LPA3 can be weakly detected during neurulation and increases until stage 45 whereas LPA5 is expressed at its highest level during maternal stages. S1P4 transcripts cannot be detected in this experiment. ODC was used as a loading control. The linearity was performed with doubling dilutions of CDNA from stage 45 embryos except stage 5 for LPA5, stage 15 for S1P5 and stage.

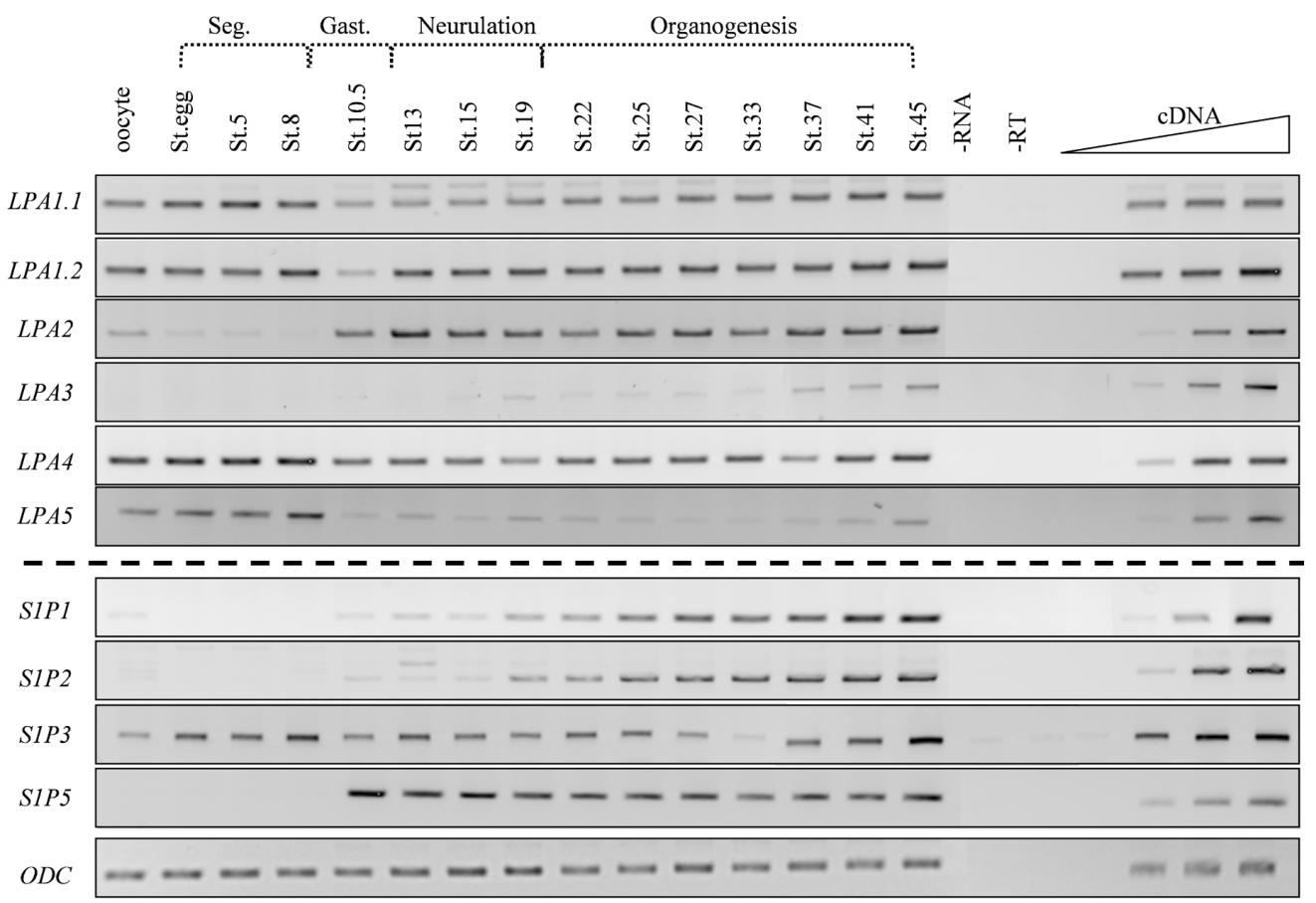

for LPA2. The major phases of embryogenesis are indicated. Seg: Segmentation; Gast: Gastrulation 
A
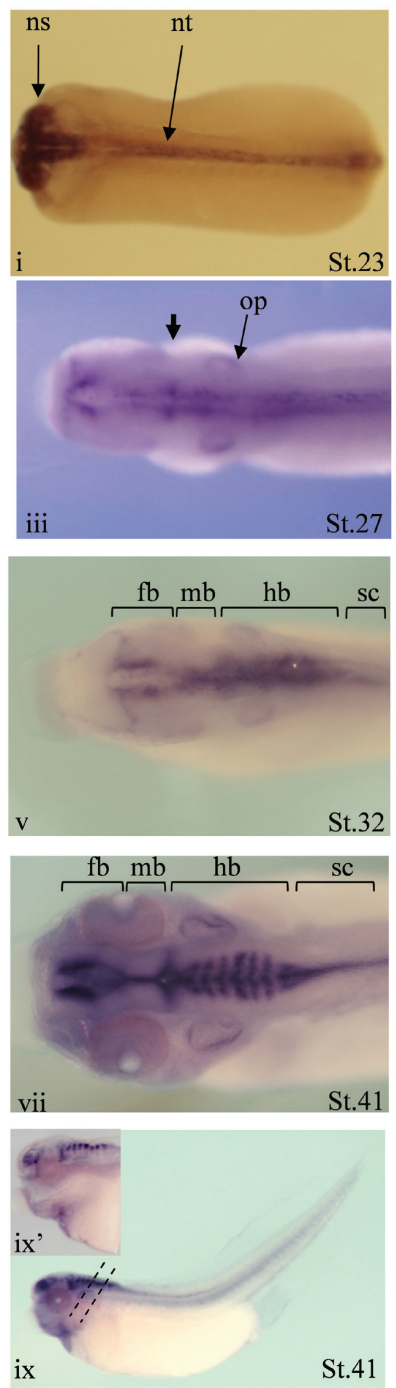

B

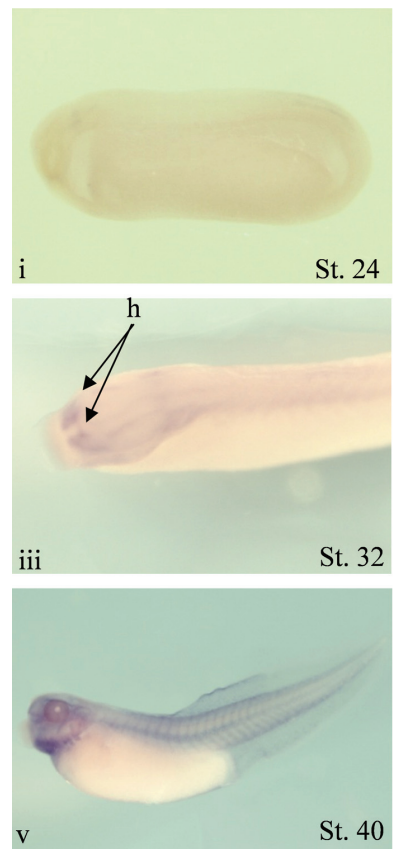

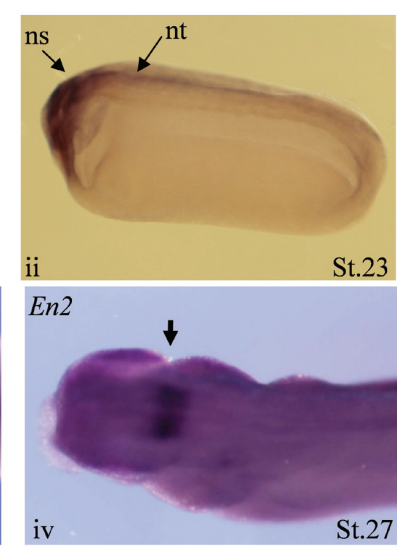
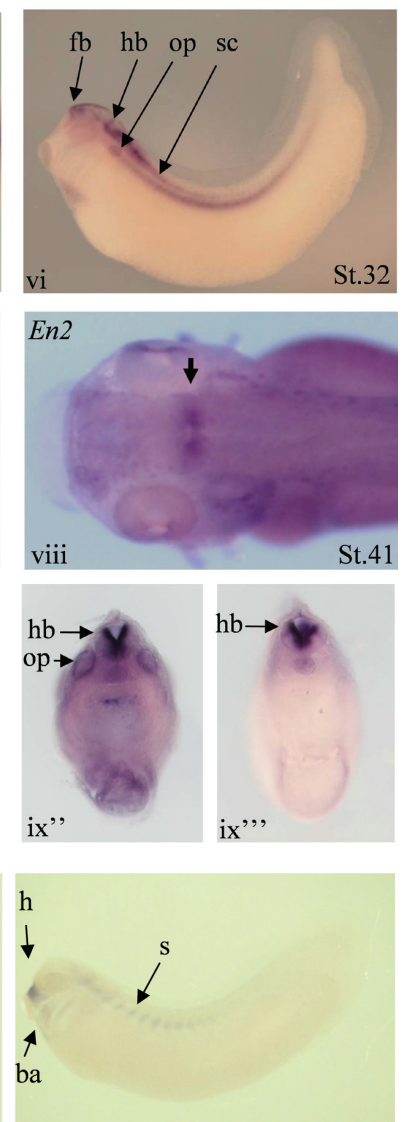

ii
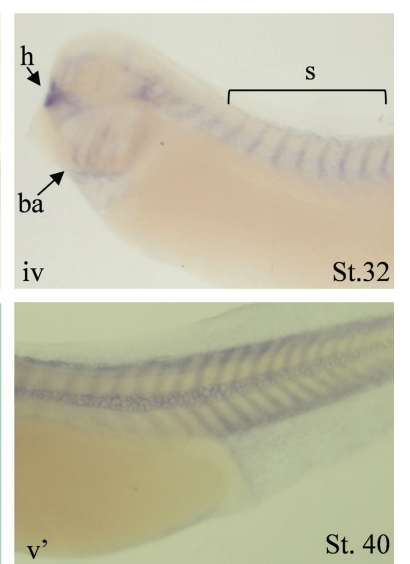

C
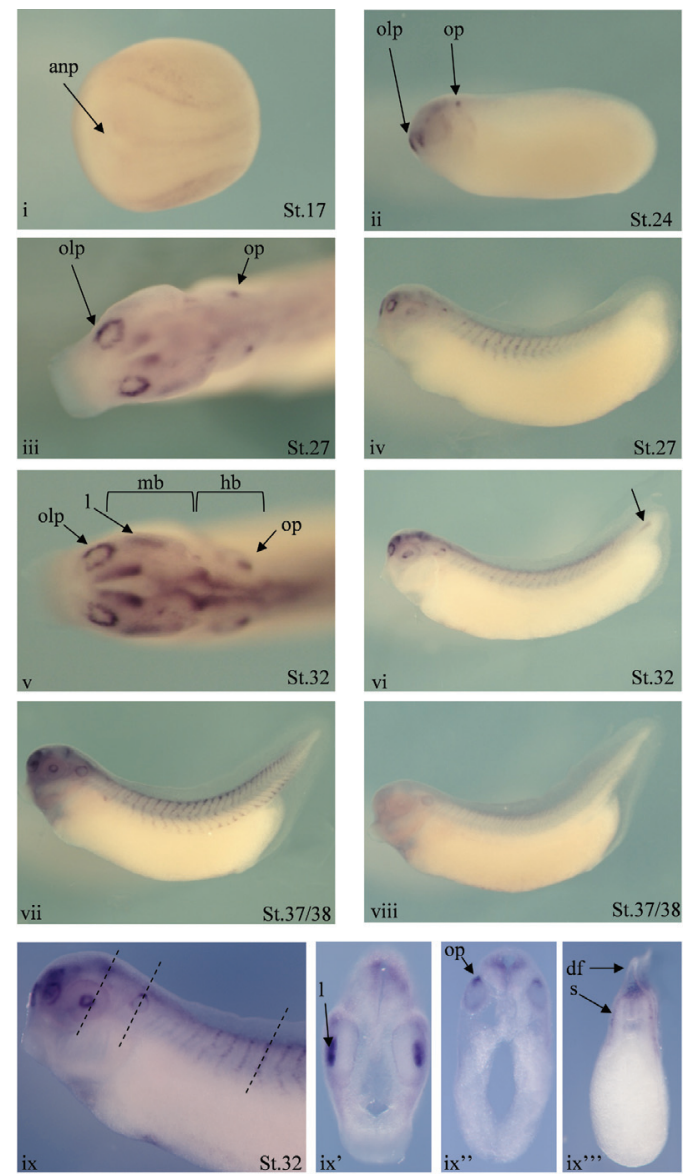

Fig. 5. Embryonic spatial expression profile of S1P genes. Whole mount in situ hybridisation with DIG-labelled RNA probe was performed on embryos from stages 6-41 for S1P genes, except for S1P4. (A) Whole mount in situ hybridisation analysis of $1 \mathrm{P} 1$ expression. Dorsal and lateral views of a cleared embryo at stage 23 (i, ii), of uncleared embryos at stage 27 (iii), at stage 32 ( $v$, vi), at stage 41 (vii, ix). Sagital section (ix') of the head at stage 41 . Tranverse sections ( $\left(x^{\prime \prime}, i x^{\prime \prime \prime}\right)$ at stage 41 . The dotted lines through the embryo (ix) correspond to planes of the transverse sections. Dorsal view of a stage 27 (iv) and stage 41 (viii) embryo stained with En2 antisense probe. The arrow indicates the midbrain/hindbrain boundary marked by En2 expression. For the lateral views, dorsal is up and anterior is left. fb: forebrain; hb: hindbrain; mb; midbrain; ns: neural system; nt: neural tube; op: otic placode; sc: spinal cord. (B) Whole mount in situ hybridisation analysis of S1P2 expression. Lateral view of cleared embryos at stage 24 (i), stage 27 (ii). Dorso-lateral view of an uncleared embryo (iii) and lateral view of a cleared embryo (iv) at stage 32. Lateral view of a uncleared embryo at stage $40(\mathrm{v})$. Detail of the stained somites of a cleared stage 40 embryo $40\left(v^{\prime}\right)$. For the lateral views, dorsal is up and anterior is left. ba: branchial arches; h: hypophyseal anlagen; s: somites. (C) Whole mount in situ hybridisation analysis of S1P5 expression. Anterior view of an embryo at stage 17 (i), lateral view at stage 24 (ii). Details of the head (iii) and lateral view (iv) of a stage 27 embryo. Details of the head (v) and lateral view (vi) of a stage 32 embryo. Lateral views at stage $37 / 38$ of an embryo hybridized with the antisense probe (vii) or with the sense probe (viii). Lateral view of the stained stage 32 embryo (ix) used for the transverse sections $\left(i x^{\prime}, i x^{\prime \prime}, i x^{\prime \prime \prime}\right)$. The dotted line through the embryo corresponds to plane of the sections. The arrow indicates the expression in the posterior notochord in the tail tip. For lateral views, dorsal is up and anterior is left. anp: anterior neural plate; df; dorsal fin; $h b$ : hindbrain; I:lens; mb: midbrain; olp: olfactory placode; op: otic placode; s: somites. 
until stage 41 (Fig. 5Avii,ix'). Sectioning of a stage 41 stained embryo showed that expression of S1P1 is limited to the dorsal region of the rhombomeres (Fig. 5 Aix'-ix"'). Transcripts are still detected at this late stage in the forebrain, midbrain, otic vesicle and spinal cord (Fig. 5Avii,ix-ix"'). No expression is detected with the sense probe in these tissues. Comparative En2 in situ hybridisation analysis showed that S1P1 is intensively expressed in the midbrain/ hindbrain boundary from stage 27 to 41 (compare Fig. 5Aiii,iv and Fig. 5Avii,viii). However, whereas En2 is more expressed at early stages, the level of expression of S1P1 is higher at late stages.

S1P2 expression is first detected in tadpole embryos, since no staining can be observed before

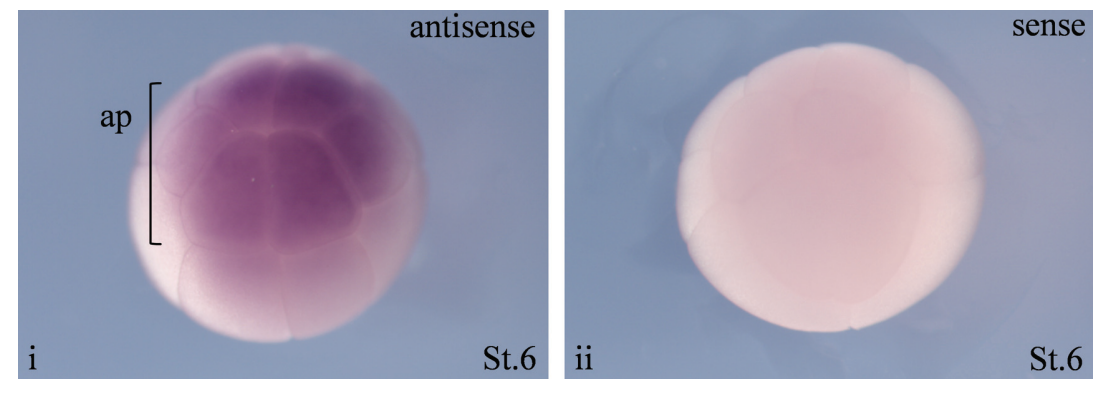

Fig. 6. Embryonic spatial expression profile of the LPA5 gene. Whole mount in situ hybridisation with DIG-labelled antisense (i) and sense (ii) LPA5 probes was performed. Expression was only detected at stage 6 in the animal pole (ap) of the embryos. Animal pole is up. stage 27 (compare Fig. 5Bi,ii). At stage 27, expression is seen in the hypophyseal anlagen (Fig. 5Bii). This staining remains until stage 32 (Fig. 5Biii,iv). Expression of S1P2in the somites and in the branchial arches can also be detected from stage 27 in cleared embryos (Fig. 5Bii). S1P2 remains expressed in these tissues until stage 40 (Fig. 5Biv-v'). S1P2 is detected in vertical stripes along the somites but its expression is weaker in the presomitic mesoderm at the caudal end of the tadpole (Fig. 5Bv). Low levels of apparent expression in the notochord are nonspecific as this level of staining was also observed with the sense probe (data not shown).

S1P5transcripts can be detected from stage 17 during neurulation (Fig. 5Ci). At this stage, S1P5is expressed in a horse-shoe shaped domain around the neural plate, characteristic of cranial placode markers such as Six1 (Schlosser, 2006). From tailbud stages, S1P5displays a restricted expression pattern with heavy staining in olfactory, optic and otic placodes (Fig. 5Cii-vii). Expression in the midbrain and hindbrain can also be detected from stage 32 (Fig. 5Cv-vii). Transient specific expression in the posterior part of the notochord in the tail tip can also be seen at stage 32 (arrow, Fig. 5Cvi). S1P5 is also found in the forming somites from stage 28 to stage 37 (Fig. 5Ciii-vii). This expression profile is specific as no expression in the nervous system, placodes or in the somites can be detected with the sense probe (Fig.

5Cviii). Sectioning of a stage 32 stained embryo (Fig. 5Cix) showed S1P5expression is limited to the lens (Fig. 5Cix'), to the dorsal region of the neural tube and the otic vesicle (Fig. 5-Cix"), to the nuclear region of the somites and the mesenchymal cells contributing to the dorsal fin (Fig. 5-Cix"').

Specific expression of the $\angle P A$ genes was only detected for $\angle P A 5$ by in situ hybridisation, suggesting that these genes are expressed at low levels during development, below the level of detection of this technique. Maternal $\angle P A 5$ transcripts were detected in the animal pole of stage 6 embryos (Fig. 6Ai). No staining was detected with the sense probe (Fig. 6Aii). Zygotic $\angle P A 5$ transcripts were however not detected, as expected from the RT-PCR analysis.

RT-PCR was also performed on a series of embryo dissections in order to confirm the expression pattern of these genes (Fig. 7). This analysis is however not quantitative as the volumes of the input cDNAs in dissected samples were equalised with respect to $O D C$ gene expression and thus the dissected samples do not represent the total expression of each gene in one embryo. However, this analysis completes and extends the in situ hybridisation analysis, especially for the LPA genes, whose expression is clearly at low levels in all tissues and was not detected by in situ hybridisation. S1P1 and 2 transcripts are very weakly detected at stage 9 in the marginal zone of the embryo.

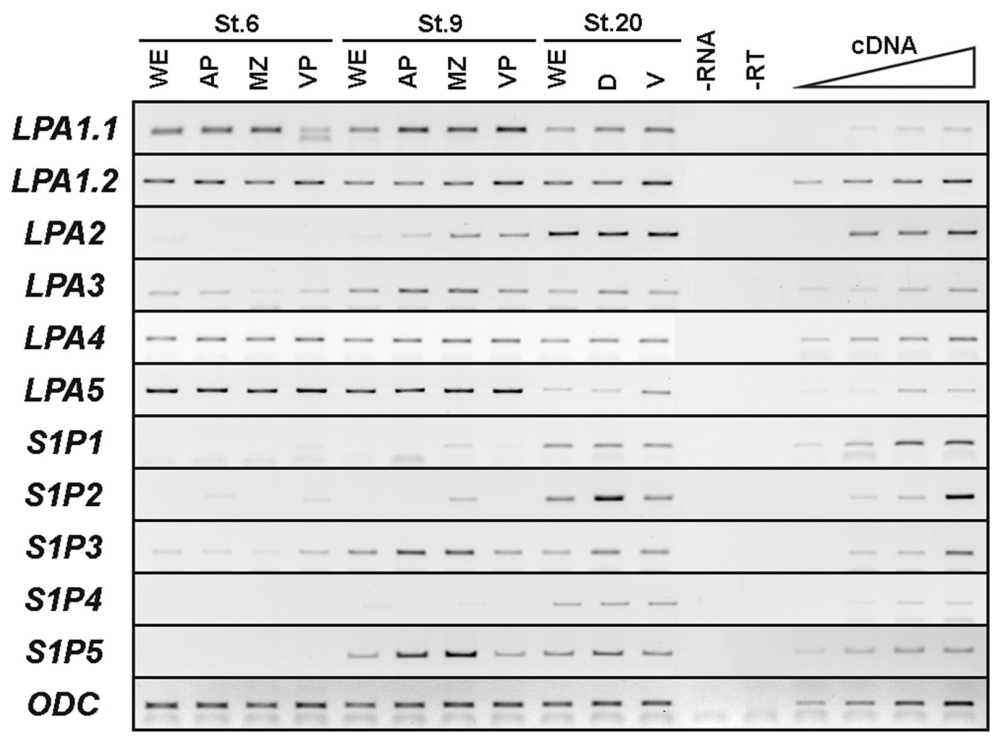

Fig. 7. Embryonic spatial expression profile of $L P A$ and S1P families genes. $R T-P C R$ analysis showing the spatial expression of the LPA and S1P genes during Xenopus laevis development. All the LPA genes appear to be expressed at the same level in the different parts of the embryos, regardless of the stage tested. Differences in the expression level can be observed for the S1P genes, with S1P1 and S1P2 only expressed in the marginal zone at stage 9, S1P3 and 4 more expressed in the animal pole and marginal zone at this stage and S1P2 more expressed in the dorsal region at stage 20. At stages 6 and 9, animal pole, marginal zone and vegetal pole containing respectively the presumptive ectoderm, mesoderm and endoderm were dissected from the embryos. At stage 20, the dorsal region of the embryo was separated from the ventral region of the embryo. ODC was used as a loading control. More cycles were added during the amplification in order to amplify genes found being expressed weakly at these early stages in Fig. 4. The linearity was performed with doubling dilutions of cDNA from stage 20 whole embryos. AP: Animal pole; D: Dorsal; MZ: Marginal zone; V: Ventral; VP: Vegetal pole; WE: Whole embryo. 
Later on, only S1P2displays a differential expression between the dorsal and ventral region of the embryo, reflecting the staining in the forming somites observed by in situhybridisation. S1P3 appears less expressed in the vegetal pole at stage 9 although at stage 6 , its transcripts can only be detected in this part of the embryo. S1P4 expression can be weakly detected at stage 20, due to an increase of cycle number of the PCR in this experiment. Finally, S1P5is more expressed in the animal pole and marginal zone at stage 9 and later on, in the dorsal region, corresponding to the placodes, neural and somitic tissues.

All $\angle P A$ genes are expressed ubiquitously in these dissected embryos, confirming the lack of any major sites of expression seen by in situ hybridisation. $\angle P A 5$ expression is the highest during early stages of development, confirming the previous results.

\section{Spatial expression of LPA and S1P gene families in tissues of the adult frog}

The spatial expression of the members of $\angle P A$ and S1P families in the adult frog was analysed by RT-PCR. As shown in Fig. 8, the members of the S1P family display broad expression patterns. S1P5is ubiquitously expressed and S1P2 is expressed in all tissues except blood cells. S1P1 and 3 are also expressed in a variety of tissues with the exception of the reproductive organs for S1P1 and stomach, pancreas and bladder for S1P3. S1P4 is preferentially expressed in the spleen and bladder although transcripts can be weakly amplified from other tissues except eyes, blood cells, stomach, and ileum.

$\angle P A$ receptors also display different expression patterns. The expression profile of $\angle P A 1.1$ and $\angle P A 1.2$ genes is quite similar being expressed in all tissues tested; however, the respective levels of their expression differs in some tissues. For example, $\angle P A 1.1$ is more expressed than $\angle P A 1.2$ in the blood cells and liver whereas the expression level of $\angle P A 1.2$ is higher than $\angle P A 1.1$ in the eyes and bladder. $\angle P A 2,4$ and 5 appear to be expressed in a wide range of organs. However, their transcripts cannot be or are only very weakly detected in some tissues. $\angle P A 2$ is absent in blood cells and muscle, $\angle P 4$ transcripts are not found in spinal cord, blood cells and ileum and $\angle P A 5$ cannot be detected in blood cells. $\angle P A 3$ displays a more restricted expression profile. Its transcripts can only be amplified in the eyes, bladder, and skin and very weakly in the brain and muscle.

Our study demonstrates that the 10 S1P/LPA receptors display overlapping expression patterns, with several tissues, such as nervous system, spleen, lung, kidney, bladder expressing several lipidic receptors at high levels. However, in the blood cells, only $\angle P A 1.1$ transcripts can be detected.

\section{Discussion}

This paper reports the cloning of 10 members of the edg gene family encoding the LPA and S1P receptors in Xenopus and the analysis of their expression profiles during development and in adult frog tissues. During this study, a complementary, systematic study of these receptors during mouse development was published (Ohuchi et al. 2008). Although some similarities can be drawn between these two studies, several differences in the expression profiles indicate potentially distinct roles that these receptors might have acquired during vertebrate evolution. The adult expression of the $10 \mathrm{LPA} / \mathrm{S} 1 \mathrm{P}$ receptors have been characterised in mammals allowing comparison with their expression patterns in the adult frog tissues (reviewed in Anliker and Chun, 2004; Meyer zu Heringdorf and Jakobs, 2007). Our analysis indicates that the expression profile of these genes has been conserved during evolution and as in mammals, with the exception of $\angle P A 3$ and S1P4, these receptors are widely expressed. Our study is the first to describe the comparative expression profile of these 10 receptors
Fig. 8. Spatial expression profile of LPA and S1P families genes in the adult frog. $R T-P C R$ was performed with total RNA extracted from Xenopus laevis adult tissues. Each gene of the two families shows a distinct expression pattern. LPA1.1 and LPA1.2 present a similar ubiquitous expression profile. LPA2, 4 and 5 were found expressed in almost all tissues studied whereas the expression of LPA3 is very specific being expressed in only 3 tissues. The S1P family members are also expressed in almost all tissues studied, with the exception of S1P4 which has high levels of expression in spleen and bladder. EF1 $\alpha$ was used as a loading control. The linearity was performed with doubling dilutions of cDNA from the following tissues: bladderforLPA3; brain forS1P1; kidney for LPA1.1, LPA1.2 and LPA2; lung for S1P5; muscle forS1P2; ovary forS1P3, LPA4 and LPA5; spleen for S1P4.

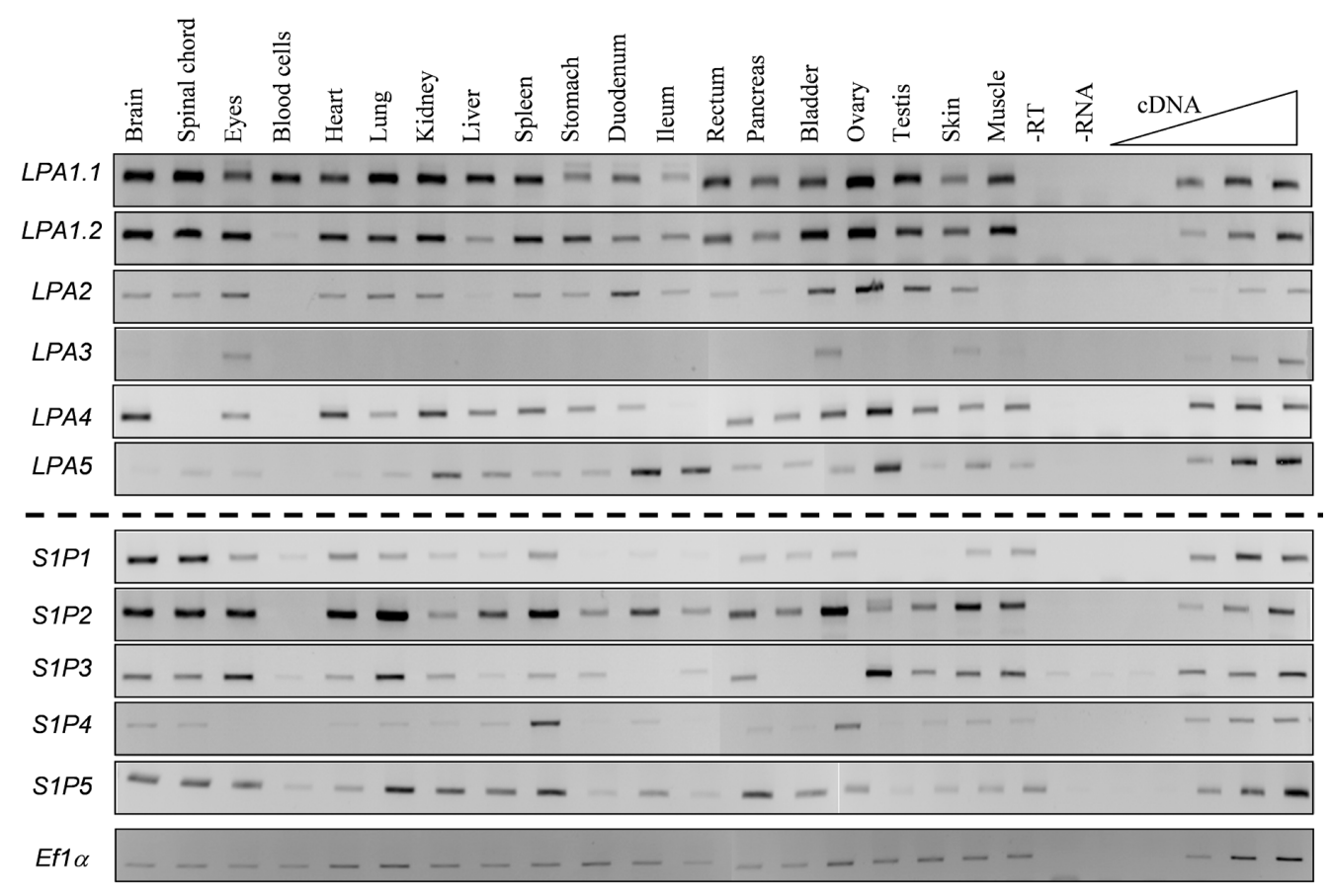


in adult tissues and to compare these patterns with those observed during embryogenesis.

\section{Evolutionary conserved members of the LPA and S1P fami- lies are present in Xenopus}

Our study reveals that all the identified members of these bioactive lipidic receptors are present in $X$. laevisand $X$. tropicalis. Xenopus laevis LPA1.1 and LPA1.2 and Xenopus tropicalis LPA2 receptors have already been cloned (Kimura et al. 2001; Lloyd et al. 2005). Although the sequences for several LPA/S1P receptors were available in databases, we cloned cDNAs for 8 of these receptors by in silico analysis, due to the increased coverage of ESTs and the $X$. tropicalis genomic DNA sequencing projects. In particular we identified sequences for $X$. tropicalis LPA3 and S1P3 that previous studies failed to identify (Lloyd et al. 2005; Ohuchi et al. 2008). Bioinformatics analysis indicated that all the sequences display the characteristic extracellular $\mathrm{N}$ terminus and the 7 transmembrane domains (TM) of these receptors which are located at the same position to the human orthologous sequences. Moreover, the G-protein coupled receptor family 1 signature and secondary modification sites for potential $\mathrm{N}$ glycosylation, phosphorylation (by protein kinase $\mathrm{C}$, casein kinase II), N-myristoylation and amidation were identified by ScanProsite analysis of the Xenopus protein sequences. The GWNC motif at the C-terminus of the TM4 is conserved in all Xenopus S1P sequences. This sequence is also found in Xenopus LPA1 and 3 , but as in its mammalian orthologs, it is not conserved in Xenopus LPA2 (GWSC in Xenopusproteins, SWHC in human sequence), LPA4 and 5 . The consensus sequence

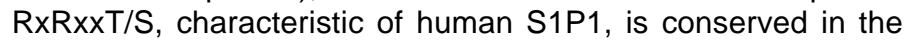
Xenopus receptors, suggesting that phosphorylation of the $T$ residue of this receptor by protein kinase B/Akt, necessary for rac activation might also occur in Xenopus (Lee et al. 2001). The amino acid residues R124, Q125, W186, R/D204 and K294, (based on human LPA1 sequence) which have been shown to be critical for interaction of LPA 1-3 with the polar head group of the LPA molecule are conserved in Xenopusproteins (Fujiwara et al. 2005; Valentine et al. 2008). The residues S114 and T187, but not Y265, of LPA4 protein (based on human sequence) which hydrogen bond with the polar head group of LPA, are conserved in Xenopusproteins (Li et al. 2009). The residues R78, H160, R261, but not R276, of LPA5 (based on human sequence) which are involved in ligand recognition, are conserved in Xenopusproteins (Williams et al. 2009), Several residues which have been implicated in the binding of S1P to its human receptor S1P1 are conserved in the other mammal orthologs (Parrill et al. 2000; Fujiwara et al. 2007). Seven of these 10 are also present in all Xenopus receptors, especially $\mathrm{R} 124$ and E125 (based on the human sequence) which are essential for S1P binding (Parrill et al. 2000). Moreover, E125 determines the ligand specificity for S1P versus LPA (Wang et al. 2001). Surprisingly, K204 which is essential for S1P binding to mouse S1P4 and receptor activation is not conserved in the Xenopusproteins (Inagaki et al. 2005). As in other mammalian S1P receptors, a basic residue in the Xenopus orthologs replaces the R292 involved in the interaction with the phosphate group of S1P (Parrill et al. 2000). Therefore we suggest that the Xenopus LPA and S1P receptors might bind their respective ligands in a similar way to the mammalian ones.

Three new receptors have been recently shown to bind bioactive lipids. The orphan GPCR GPR87 receptor can bind LPA (Tabata et al. 2007). The P2Y5, identified as LPA6, and LPA8/P2Y10 receptors, belonging to the nucleotide $\mathrm{P} 2 \mathrm{Y}$ receptors family, are activated by LPA and LPA/S1P respectively (Murakami et al. 2008; Yanagida et al. 2009). BLAST search identified $X$. laevis and tropicalis clones similar to these mammalian sequences.

\section{Expression of S1P genes suggests specific roles in Xenopus}

The embryonic gene expression profile of the S1Pgenes has been reported in other vertebrate species, especially in the mouse in which a comparative analysis of their expression during development has been published allowing direct comparison with our study (Ohuchi et al. 2008; Meng and Lee, 2009). Three members of S1P receptor family display specific and distinct expression profiles during frog embryogenesis. S1P3expression is not regulated during embryogenesis and we failed to detect its expression by in situhybridisation. In mouse and chick embryos, this receptor is expressed widely in non neuronal cells but nullS1P3 mice display no gross phenotype suggesting that this receptor is not required for normal development and function (Ishii et al. 2001; Ohuchi et al. 2008; Meng and Lee, 2009). Our result shows that S1P4 is only weakly expressed during embryogenesis. In the mouse, S1P4 is first expressed ubiquitously, but its expression is not detected or is only at low levels after E12.5, suggesting that like in the frog, this gene might not play a major role during embryogenesis although expression in specific neural tissues might suggest a potential role during neural formation (Ohuchi et al. 2008; Meng and Lee, 2009). No knock-out mice are available to confirm this hypothesis. However, S1P4 adult expression is mostly highly detected in the frog spleen, as in both human and mouse, suggesting potential roles of this receptor in lymphoid cell functions (Gräler et al. 1998).

The zygotic expression of S1P1, S1P2 and S1P5 is switched on at the same stage, during early gastrulation. However, their distinct spatial expression profiles suggest specific roles during embryogenesis. S1P2 is majorly expressed in the developing somites and at stage 9, its expression is detected in the marginal zone. The mouse ortholog is expressed in somites and also in the mesenchyme of several organs (Ohuchi et al. 2008; Meng and Lee, 2009). Moreover, the zebrafish S1P2 or mil gene is expressed in the paraxial mesodermal cells which give rise to the somites (Kupperman et al. 2000). This mesodermal expression pattern has been conserved during evolution and Xenopus S1P2 might play a role during mesoderm formation. However, due to the disparate phenotypes between mouse and zebrafish mutants, it is difficult to speculate as to the potential phenotype following misexpression in Xenopus. S1P2 is not expressed in the mouse and frog developing nervous system but found in the developing branchial arches, emphasizing the potential conservation of the function of this receptor in mammals and non-mammalian vertebrates (Ohuchi et al. 2008; Meng and Lee, 2009).

Xenopus S1P1 transcripts are only localised in the developing nervous system and this exclusive expression of S1P1in the brain is in agreement with the expression profile of its ortholog in zebrafish (Im et al. 2000). This exclusive neuronal expression contrasts with the expression profile of mammalian S1P1 receptors. In mouse and rat, this receptor is more widely expressed, although strong expression can be detected in the nervous system from E14 (Lado et al. 1994; Liu and Hla, 1997; McGiffert 
et al. 2002). Earlier expression in the forebrain can be detected from $E 10.5$, although the major domain of expression at this stage is the developing heart and blood vessels (Ohuchi et al. 2008). A similar expression profile has been recently published in chick embryos (Meng and Lee, 2009). However, the phenotypic analysis of the null-S1P1 mice demonstrated the role of this receptor during neural development, consistent with its expression in the neuroepitheliun and ventricular zone of the brain and neural tube (Mizugishi et al. 2005; Meng and Lee, 2009). We did not detect zygotic expression of S1P1 outside the nervous system. Moreover, the high level of its expression in the adult brain and spinal cord suggests that, as in mammals, S1P1 must be the receptor mediating the effects of S1P in the nervous system.

The expression profile of S1P5 is quite different between Xenopus and mammals. In the adult, S1P5 is ubiquitously expressed in the adult frog whereas its expression is more restricted in mammalian tissues, the exact profile depending on the species analysed (Im et al. 2001; Niedernberg et al. 2002). During embryogenesis, S1P5is expressed in the somites, lens, otic vesicle and in the mesoderm in the caudal region of mouse and Xenopus embryos but mouse S1P5is majorly expressed in the presomitic mesoderm whereas Xenopus S1P5 is a marker for cranial placodes (Ohuchi et al. 2008; Meng and Lee, 2009). Moreover, no specific signals can be detected after E12.5 whereas its expression can still be detected at stage 41 in the tadpole. These data suggest that S1P5 might play distinct and different roles in mouse and Xenopus. This is in agreement with the in vitro observation that rS1P5 display anti-proliferative effects in contrast to hS1P5 (Niedernberg et al. 2002). Moreover, a recent study revealed strong expression in the mouse nervous system from E.14.5, suggesting that the expression profile of this receptor in mammals is still uncertain (Meng and Lee, 2009). Our protein sequence analysis showed that S1P5 is the least Edg conserved member, emphasizing potential different functional roles this receptor might have acquired during evolution. However, despite lack of major obvious phenotype, S1P5 null mice display defects in oligodendroglial cellular functions and natural killer cell trafficking (Jaillard et al. 2005; Walzer et al. 2007). Xenopus S1P5 is expressed in developing cranial placodes. S1P has been involved in cell migration during development and we suggest that S1P5 might play a crucial role during placode cell migration as it has been suggested for S1P1 and vascular smooth muscle cells migration or S1P2 and cardiac precursor cells migration (Kupperman et al. 2000; Liu et al. 2000).

\section{LPA expression suggests housekeeping functions in Xeno- pus}

LPA1 and LPA2 have already been cloned in Xenopus (Kimura et al. 2001; Lloyd et al. 2005). Our results indicate a wider distribution for $\angle P A 1.1$ and $\angle P A 1.2$ in adult frog than previously published, but confirm that these transcripts are strongly expressed in the nervous system and ovary (oocytes) (Kimura et al. 2001). Therefore, these differences probably reflect the increased sensitivity of RT-PCR analysis over the previously used NorthernBlot analysis. The expression profiles of Xenopus LPA1 and 2 have been published previously but no in situ hybridisation data are available for these genes (Lloyd et al. 2005). Our RT-PCR analysis is consistent with published temporal expression profile for these genes and is included for completeness in our analysis.
As in mammals, LPA1.1, LPA1.2, LPA2are ubiquitous whereas $\angle P A 4$ and $\angle P A 5$ are expressed at low level in many tissues but at higher level in ovary and small intestine respectively (Noguchi et al. 2003; Lee et al. 2006). However, $\angle P A 3$ is ubiquitously expressed in mammals whereas its expression is only detected in the amphibian bladder, eyes and skin (Bandoh et al. 1999; Im et al. 2000). In embryos, we could only detect $\angle P A 5$ by in situ hybridisation, the other LPA receptors being expressed ubiquitously at low level by RT-PCR, certainly below the level of detection of the in situ hybridisation technique. In mouse, the expression of all $\angle P A$ family members display specific but overlapping domains but the intensity of the signals is weak, except for LPA1, suggesting a low level of expression for these genes (Ohuchi et al. 2008).

Our RT-PCR results suggest that the 5 LPA receptors might display a similar ubiquitous embryonic expression pattern, pointing towards housekeeping cellular functions for these receptors during frog development. This is in agreement with the phenotype obtained following miss-expression of the LPA1 and 2 receptors in Xenopus, which demonstrate the role of LPA signalling in cortical actin assembly and cytoarchitecture (Lloyd et al. 2005). However, their temporal expression is regulated during Xenopus embryogenesis suggesting some developmental role. The high level of $\angle P A 5$ expression during maternal stages suggests it might be the major receptor to mediate LPA signalling during the early phases of development. Hydrolysis of lipids is critical for fertilization and LPC has been suggested to induce the membrane fusion needed for the sperm acrosomal reaction and sphingomyelin (SM) may play a role during membrane fusion and egg-sperm interactions by stabilizing rafts (Petcoff et al. 2008). As S1P3 is the only $S 1 P$ receptor member to be maternally expressed, it may be also involved in mediating the actions of S1P during these early phases of embryogenesis.

We have previously published the expression profile of enpp2a and enpp2b genes encoding for Xenopus laevis autotaxin proteins, the major lysoPLD enzyme producing extracellular LPA (Massé et al. 2010). Surprisingly, no correlations between the expression profiles obtained by in situ hybridisation of these enzymes and the $\angle P A 1-5$ receptors can be made, except that enpp2a and enpp2b display a similar temporal expression to $\angle P A 1.1$ and $\angle P A 1.2$. One possibility is that the different receptors have redundant functions as it has been suggested in rodents (see Choi et al. 2008) and therefore a low level of expression of each receptor is sufficient to mediate the actions of LPA, especially since these 5 receptors seem to be ubiquitously expressed. It is also possible that the three new LPA receptors might display a more similar expression profile to the enpp2 genes, although $\angle P A 6$ seems to be highly expressed in the skin/ectoderm from EST analysis. This is in agreement with the involvement of the human protein in the regulation of hair follicle development and hair growth (Pasternack et al. 2008; Shimomura et al. 2009). The analysis of their expression is currently in progress in the laboratory. Furthermore, it is more than possible that not all the LPA receptors have yet been identified and new orphan GPCR receptors might be shown to bind LPA.

In conclusion, our study demonstrates that at least 10 of the lipidic receptors are present in the frogs. Their wide adult distribution suggests that the S1P and LPA molecules might regulate diverse cellular functions in all amphibian tissues, but especially 
in the nervous system, spleen and kidney as it has been shown in mammals (reviewed in Fukushima, 2004; Jo et al. 2008). However, the embryonic expression profiles of these receptors suggest potential distinct and novel roles for S1P1, S1P2 and S1P5 and LPA5 and therefore for their ligands during development. S1P and LPA signalling pathways have been conserved during evolution however, their receptors have only been identified in vertebrates (Oskouian and Saba, 2004). Therefore, studying their functions in frogs should bring new evidence of the roles they have acquired during vertebrate evolution and also to their involvement in human pathologies. Since we have previously published the cloning and the developmental expression patterns of the enppfamily genes whose members can generate LPA and S1P (Massé et al. 2010), as a consequence of this work we can now misexpress both enzymes and receptors to identify their combinatorial roles in development. Xenopus therefore provides an excellent model in which to dissect these signalling pathways and establish their roles during embryogenesis.

\section{Materials and Methods}

\section{Bioinformatics}

$X$. laevis and $X$. tropicalis EST clones were identified by a TBLASTN (Basic Local Alignment Search Tool) search on the NCBI EST others databases using the sequence from the orthologous human proteins (Altschul et al. 1990). Genomic X. tropicalis sequences were identified by the same search on the Joint Genome Institute (JGI) website (http:// genome.jgi-psf.org/Xentr4/Xentr4.home.html). Accession numbers of all sequences used in this study are given in Supplementary Table 1B. Pairwise alignments were performed using the Needle program based on Needleman-Wunsch global alignment algorithm (European Bioinformatics Institute website) (Needleman and Wunsch, 1970). Multiple alignment was performed using the software CLUSTALW (Thompson et al. 1994). For phylogeny studies, receptor sequences were aligned using the GeneBee algorithm and a phylogenetic tree produced using the PHYLIP program (Brodsky et al. 1992). Conceptual translation of cDNA and protein sequence analysis was performed on the ExPaSy website http:/ /www.expasy.org/tools/\#ptm).

\section{DNA}

The identified I.M.A.G.E clones were ordered from Geneservice Ltd, Cambridge (Supplementary Table 1B). DNA was extracted from several individual colonies, verified by restriction analysis and sequenced from both strands. When required, primers were designed to complete the sequencing of each clone.

\section{Embryo culture and dissections}

Culture of the embryos was performed as described previously (Massé et al. 2004). The embryos were staged according to Nieuwkoop and Faber, 1994. Dissections of appropriately staged embryos were performed in Barth X using forceps and an eyebrow hair knife.

\section{$R T-P C R$}

RNA extraction from embryonic and adult tissues and cDNA synthesis were performed as described by Barnett et al. 1998. For each gene, specific primers were designed based on the $X$. laevis sequences (Supplementary Table 2). Each PCR was optimised and verified by sequencing as described previously. PCR was then carried out with nonradioactive nucleotides according to details in Supplementary Table 2. For each experiment, the quantity of input cDNA was determined by equalisation of the samples with a constant gene, either $O D C$ (Bassez et al. 1990) or Ef1 $\alpha$ Mohun et al. 1989). Linearity of signal was controlled by carrying out PCR reactions on doubling dilutions of CDNA, illustrated by the triangle. Negative controls were performed as indicated.

\section{Whole-mount in situ hybridisation}

Whole-mount in situ hybridisation was performed essentially as described in Harland, 1991 with several modifications (Massé et al. 2010). In order to minimise the cross-reactions between homologous genes, specific antisense probes were made of each gene, preferentially designed in the 3'UTR of each receptor sequence. In each case, sense probes were used to control the specificity of the staining. Details of the probes are documented in Supplementary Table 3.

\section{Acknowledgments}

We thank $P$. Jarrett for the maintenance of the breeding frogs. This work was supported by the Wellcome Trust, Grant no 082071.

\section{References}

ALLENDE ML, YAMASHITA T, PROIA RL (2003) G-protein-coupled receptor S1P1 acts within endothelial cells to regulate vascular maturation. Blood102: 3665 3667.

ALLENDE ML, DREIER JL, MANDALA S, PROIA RL (2004) Expression of the sphingosine 1-phosphate receptor, S1P1, on T-cells controls thymic emigration. J Biol Chem 279: 15396-15401.

ALTSCHUL SF, GISH W., MILLER W, MYERS EW, LIPMAN DJ (1990) Basic local alignment search tool. J Mol Bio/215: 403-410.

ANLIKER B, CHUN J (2004) Cell surface receptors in lysophospholipid signalling Semin Cell Dev Biol 15: 457-465.

BANDOH K, AOKI J, HOSONO H, KOBAYASHI S, KOBAYASHI T, MURAKAMIMUROFUSHI K, TSUJIMOTO M, ARAI H, INOUE K (1999) Molecular cloning and characterization of a novel human G-protein-coupled receptor, EDG7, for lysophosphatidic acid. J.Biol.Chem 274: 27776-27785.

BARNETT MW, OLD RW, JONES EA (1998) Neural induction and patterning by fibroblast growth factor, notochord and somite tissue in Xenopus. Dev Growth Differ 40: 47-57.

BASSEZ T, PARIS J, OMILLI F, DOREL C, OSBORNE HB (1990) Post-transcriptional regulation of ornithine decarboxylase in"Xenopus laevis oocytes. Deve/opment 110: 955-962.

BAUDHUIN LM, JIANG Y, ZASLAVSKY A, ISHII I, CHUN J, XU Y (2004) S1P3mediated Akt activation and cross-talk with platelet-derived growth factor receptor (PDGFR). FASEB J18: 341-343.

BREATHNACH R, CHAMBON P (1981) Organization and expression of eucaryotic split genes coding for proteins. Annu Rev Biochem 50: 349-383.

BRINKMANN V (2007) Sphingosine 1-phosphate receptors in health and disease: mechanistic insights from gene deletion studies and reverse pharmacology. Pharmacol Ther 115: 84-105.

BRODSKY L.I., VASILIEV A.V., KALAIDZIDIS YA.L., OSIPOV YU.S., TATUZOV R.L., FERANCHUK S.I. (1992) GeneBee: the Program Package for Biopolymer Structure Analysis. Dimacs 8: 127-139.

CHOI JW, LEE CW, CHUN J (2008) Biological roles of lysophospholipid receptors revealed by genetic null mice: an update. Biochim Biophys Acta 1781: 531-539.

CHUN J, GOETZL EJ, HLA T, IGARASHI Y, LYNCH KR, MOOLENAAR W, PYNE S, TIGYIG (2002) International Union of Pharmacology. XXXIV. Lysophospholipid receptor nomenclature. Pharmacol Rev 54: 265-269.

CONTOS JJ, ISHII I, CHUN J (2000a) Lysophosphatidic acid receptors. Mol Pharmaco/58: 1188-1196.

CONTOS JJ, FUKUSHIMA N, WEINER JA, KAUSHAL D, CHUN J (2000b) Requirement for the IpA1 lysophosphatidic acid receptor gene in normal suckling behavior. Proc Natl Acad Sci USA 97: 13384-13389.

CONTOS JJ, ISHII I, FUKUSHIMA N, KINGSBURY MA, YE X, KAWAMURA S, BROWN JH, CHUN J (2002) Characterization of Ipa(2) (Edg4) and Ipa(1)/lpa(2) (Edg2/Edg4) lysophosphatidic acid receptor knockout mice: signaling deficits without obvious phenotypic abnormality attributable to Ipa(2). Mol Cel/ Bio 22: 6921-6929.

DUAN RD (2006) Alkaline sphingomyelinase: An old enzyme with novel implications. Bioc Biochim Biophys Acta 1761: 281-291. 
ESTIVILL-TORRÚS G, LLEBREZ-ZAYASP, MATAS-RICOE, SANTÍN L, PEDRAZA C, DE DIEGO I, DEL ARCO I, FERNÁNDEZ-LLEBREZ P, CHUN J, DE FONSECA FR (2008) Absence of LPA1 signaling results in defective cortical development. Cereb Cortex 18: 938-950.

FUJIWARA Y, SARDAR V, TOKUMURA A, BAKER D, MURAKAMI-MUROFUSHI K, PARRILL A, TIGYI G (2005) Identification of residues responsible for ligand recognition and regioisomeric selectivity of lysophosphatidic acid receptors expressed in mammalian cells. J Biol Chem 280: 35038-35050.

FUJIWARA Y, OSBORNE DA, WALKER MD, WANG DA, BAUTISTA DA, LILIOM K, VAN BROCKLYN JR, PARRILL AL, TIGYI G (2007) Identification of the hydrophobic ligand binding pocket of the S1P1 receptor. JBio/Chem282: 23742385.

FUKUSHIMA N (2004) LPA in neural cell development. J Cell Biochem 92: 9931003.

GRÄLER MH, BERNHARDT G, LIPP M (1998) EDG6, a novel G-protein-coupled receptor related to receptors for bioactive lysophospholipids, is specifically expressed in lymphoid tissue. Genomics 53: 164-169.

HARLAND RM (1991) In situ hybridization: an improved whole-mount method for Xenopus embryos. Methods Cell Bio/36: 685-695.

HERR DR, GRILLET N, SCHWANDER M, RIVERA R, MÜLLER U, CHUN J (2007) Sphingosine 1-phosphate ( $\mathrm{S} 1 \mathrm{P})$ signaling is required for maintenance of hair cells mainly via activation of S1P2. JNeurosci27: 1474-1478.

IM DS, UNGAR AR, LYNCH KR. (2000) Characterization of a zebrafish (Danio rerio) sphingosine 1-phosphate receptor expressed in the embryonic brain. Biochem Biophys Res Commun 279: 139-143.

IM DS, CLEMENS J, MACDONALD TL, LYNCH KR (2001) Characterization of the human and mouse sphingosine 1-phosphate receptor, S1P5 (Edg-8): structureactivity relationship of sphingosine1-phosphate receptors. Biochemistry 40: 14053-14060.

INAGAKI Y, PHAM TT, FUJIWARA Y, KOHNO T, OSBORNE DA, IGARASHI Y, TIGYI G, PARRILL AL (2005) Sphingosine 1-phosphate analogue recognition and selectivity at S1P4 within the endothelial differentiation gene family of receptors. Biochem J389: 187-195.

ISHII I, FRIEDMAN B, YE X, KAWAMURA S, MCGIFFERT C, CONTOS JJ, KINGSBURY MA, ZHANG G, BROWN JH, CHUN J (2001) Selective loss of sphingosine 1-phosphate signaling with no obvious phenotypic abnormality in mice lacking its G protein-coupled receptor, LP(B3)/EDG-3. J Biol Chem 276: 33697-33704.

ISHII I, YE X, FRIEDMAN B, KAWAMURA S, CONTOS JJ, KINGSBURY MA, YANG AH, ZHANG G, BROWN JH, CHUN J (2002) Marked perinatal lethality and cellular signaling deficits in mice null for the two sphingosine 1-phosphate (S1P) receptors, S1P(2)/LP(B2)/EDG-5 and S1P(3)/LP(B3)/EDG-3. JBio/Chem 277: 25152-25159.

ISHII S, NOGUCHI K, YANAGIDA K (2009) Non-Edg family lysophosphatidic acid (LPA) receptors Prostaglandins and Other Lipid Mediators 89: 57-65.

JAILLARD C, HARRISON S, STANKOFF B, AIGROT MS, CALVER AR, DUDDY G, WALSH FS, PANGALOS MN, ARIMURA N, KAIBUCHI K, ZALC B, LUBETZK C (2005) Edg8/S1P5: an oligodendroglial receptor with dual function on process retraction and cell survival. JNeurosci 25: 1459-1469.

JO S-K, BAJWA A, AWAD AS, LYNCH KR, OKUSA MD (2008) Sphingosine-1phosphate receptors: biology and therapeutic potential in kidney disease. Kidney Int 73: 1220-1230.

KABASHIMA K, HAYNES NM, XU Y, NUTT SL, ALLENDE ML, PROIA RL, CYSTER JG (2006) Plasma cell S1P1 expression determines secondary lymphoid organ retention versus bone marrow tropism. J Exp Med203: 26832690.

KIMURA Y, SCHMITT A, FUKUSHIMA N, ISHII I, KIMURA H, NEBREDA AR, CHUN J (2001) Two novel Xenopus homologs of mammalian LP(A1)/EDG-2 function as lysophosphatidic acid receptors in Xenopus oocytes and mammalian cells. J Bio/ Chem 276: 15208-15215.

KLUK MJ, HLA T (2002) Signaling of sphingosine-1-phosphate via the S1P/EDGfamily of G-protein-coupled receptors. Biochim Biophys Acta 1582: 72-80.

KONO M, MI Y, LIU Y, SASAKI T, ALLENDE ML, WU YP, YAMASHITA T, PROIA $R L$ (2004) The sphingosine-1-phosphate receptors S1P1, S1P2, and S1P3 function coordinately during embryonic angiogenesis. J Biol Chem279: 2936729373.
KONO M, BELYANTSEVA IA, SKOURA A, FROLENKOV GI, STAROST MF, DREIER JL, LIDINGTON D, BOLZ SS, FRIEDMAN TB, HLA T, PROIA RL (2007) Deafness and stria vascularis defects in S1P2 receptor-null mice. J Biol Chem 282: 10690-10696.

KUPPERMAN E, AN S, OSBORNE N, WALDRON S, STAINIER DY (2000) A sphingosine-1-phosphate receptor regulates cell migration during vertebrate heart development. Nature 406: 192-195.

LADO DC, BROWE CS, GASKIN AA, BORDEN JM, MACLENNAN AJ (1994) Cloning of the rat edg-1 immediate-early gene: expression pattern suggests diverse functions. Gene 149: 331-336.

LEE MJ, THANGADA S, PAIK JH, SAPKOTA GP, ANCELLIN N, CHAE SS, WU M, MORALES-RUIZ M, SESSA WC, ALESSI DR, HLA T. (2001) Akt-mediated phosphorylation of the $\mathrm{G}$ protein-coupled receptor EDG-1 is required for endothelial cell chemotaxis. Mol Cel/8: 693-704.

LEE CW, RIVERA R, GARDELL S, DUBIN AE, CHUN J. (2006) GPR92 as a new G12/13- and Gq-coupled lysophosphatidic acid receptor that increases cAMP, LPA5 J Biol Chem 281: 23589-23597.

LI G, MOSIER PD, FANG X, ZHANG Y (2009) Toward the three-dimensional structure and lysophosphatidic acid binding characteristics of the LPA(4)/ p2y(9)/GPR23 receptor: A homology modeling study. JMo/GraphMode/28: 7079

LIN S, WANG D, IYER S, GHALEB AM, SHIM H, YANG VW, CHUN J, YUN CC (2009). The absence of LPA2 attenuates tumor formation in an experimental model of colitis-associated cancer. Gastroenterology 136: 1711-1720.

LIU CH, HLA T (1997) The mouse gene for the inducible G-protein-coupled receptor edg-1. Genomics 43: 15-24.

LIU Y, WADA R, YAMASHITA T, MI Y, DENG CX, HOBSON JP, ROSENFELDT HM, NAVA VE, CHAE SS, LEE MJ, LIU CH, HLA T, SPIEGEL S, PROIA RL. (2000) Edg-1, the G protein-coupled receptor for sphingosine-1-phosphate, is essential for vascular maturation. J Cli Invest 106: 951-961.

LIU S, UMEZU-GOTO M, MURPH M, LU Y, LIU W, ZHANG F, YU S, STEPHENS LC, CUI X, MURROW G, COOMBES K, MULLER W, HUNG MC, PEROU CM, LEE AV, FANG X, MILLS GB (2009) Expression of Autotaxin and Lysophosphatidic Acid Receptors Increases Mammary Tumorigenesis, Invasion, and Metastases Cancer Cel/15: 539-550.

LLOYD B, TAO Q, LANG S, WYLIE C (2005) Lysophosphatidic acid signaling controls cortical actin assembly and cytoarchitecture in Xenopus embryos. Development 132: 805-816.

LORENZ JN, AREND LJ, ROBITZ R, PAUL RJ, MACLENNAN AJ (2007) Vascular dysfunction in S1P2 sphingosine 1-phosphate receptor knockout mice. $A m J$ Physiol Regul Integr Comp Physio/292: 440-446.

LYNCH KR (2002) Lysophospholipid receptor nomenclature. Biochim Biophys Acta 1582: $70-71$

MCGIFFERT C, CONTOS JJ, FRIEDMAN B, CHUN J (2002) Embryonic brain expression analysis of lysophospholipid receptor genes suggests roles for $\mathrm{s} 1 \mathrm{p}(1)$ in neurogenesis and $\mathrm{s} 1 \mathrm{p}(1-3)$ in angiogenesis. FEBS Lett531: 103-108.

MACLENNAN AJ, BENNER SJ, ANDRINGA A, CHAVES AH, ROSING JL, VESEY R, KARPMAN AM, CRONIER SA, LEE N, ERWAY LC, MILLER ML (2006) The S1P2 sphingosine 1-phosphate receptor is essential for auditory and vestibular function. Hear Res 220: 38-48.

MASSÉ K, BALDWIN R, BARNETT MW, JONES EA (2004) X-epilectin: a novel epidermal fucolectins regulated by BMP signalling. Int JDev Bio/48: 1119-1129.

MASSÉ K, BHAMRA S, ALLSOP G, DALE N, JONES EA (2010) enpp nucleotidases: cloning, conservation and developmental restriction. Int J Dev Bio/54: 181-193

MATLOUBIAN M, LO CG, CINAMON G, LESNESKI MJ, XU Y, BRINKMANN V, ALLENDE ML, PROIA RL, CYSTER JG (2004) Lymphocyte egress from thymus and peripheral lymphoid organs is dependent on S1P receptor 1. Nature 427: 355-360.

MENG H, LEE VM (2009) Differential expression of Sphingosine-1-Phosphate receptors 1-5 in the developing nervous system. Dev Dyn 238: 487-500.

MEYER ZU HERINGDORF D, JAKOBS KH (2007) Lysophospholipid receptors: signalling, pharmacology and regulation by lysophospholipid metabolism. Biochim Biophys Acta 1768: 923-940.

MILLS GB, MOOLENAAR WH (2003) The emerging role of lysophosphatidic acid in cancer. Nat Rev Cancer 3: 582-591. 
MIZUGISHI K, YAMASHITA T, OLIVERA A, MILLER GF, SPIEGEL S, PROIA RL (2005) Essential role for sphingosine kinases in neural and vascular development. Mol Cel/ Biol 25: 11113-11121.

MOHUN TJ, TAYLOR MV, GARRETT N, GURDON JB (1989) The CArG promoter sequence is necessary for muscle-specific transcription of the cardiac actin gene in Xenopus embryos EMBO J8: 1153-1161.

MOOLENAAR WH, VAN MEETEREN LA, GIEPMANS BN (2004) The ins and outs of lysophosphatidic acid signaling. Bioessays 26: 870-881.

MURAKAMI M, SHIRAISHI A, TABATA K, FUJITA N (2008) Identification of the orphan GPCR, P2Y(10) receptor as the sphingosine-1-phosphate and lysophosphatidic acid receptor. Biochem Biophys Res Commun 371: 707-712.

NEEDLEMAN SB, WUNSCH CD (1970) A general method applicable to the search for similarities in the amino acid sequence of two proteins. JMol Bio/48: 443-453.

NIEDERNBERG A, SCHERER CR, BUSCH AE, KOSTENIS E. (2002) Comparative analysis of human and rat $\operatorname{S1P}(5)($ edg8): differential expression profiles and sensitivities to antagonists. Biochem Pharmaco/64: 1243-1250.

NIEUWKOOP PD, FABER J (1994) Normal table of Xenopus laevis (Daudin). Garland Publishing, Inc. New York.

NOGUCHI K, ISHII S, SHIMIZU T (2003) Identification of p2y9/GPR23 as a novel $G$ protein-coupled receptor for lysophosphatidic acid, structurally distant from the Edg family. J Biol Chem 278: 25600-25606.

OHUCHI H, HAMADA A, MATSUDA H, TAKAGI A, TANAKA M, AOKI J, ARAI H, NOJI S (2008) Expression patterns of the lysophospholipid receptor genes during mouse early development Dev Dyn 237: 3280-3294.

OSBORNE N, STAINIER DY (2003) Lipid receptors in cardiovascular development. Annu Rev Physio/65: 23-43.

OSKOUIAN B, SABA JD (2004) Death and taxis: what non-mammalian models tell us about sphingosine-1-phosphate. Semin Cel/ Dev Biol15: 529-540.

PARRILL AL, WANG D, BAUTISTA DL, VAN BROCKLYN JR, LORINCZ Z, FISCHER DJ, BAKER DL, LILIOM K, SPIEGEL S, TIGYI G (2000) Identification of $E d g 1$ receptor residues that recognize sphingosine 1-phosphate. JBiol Chem 275: 39379-39384.

PASTERNACK SM, VON KÜGELGEN I, ABOUD KA, LEE YA, RÜSCHENDORF F, VOSSK, HILLMER AM, MOLDERINGS GJ, FRANZT, RAMIREZA, NÜRNBERG P, NÖTHEN MM, BETZ RC (2008) G protein-coupled receptor P2Y5 and its ligand LPA are involved in maintenance of human hair growth. Nat Genet 40 : 329-334.

PETCOFF DW, HOLLAND WL, STITH BJ (2008) Lipid levels in sperm, eggs, and during fertilization in Xenopus laevis. J Lipid Res 49: 2365-2378.

SABA JD (2004) Lysophospholipids in development: Miles apart and edging in. $J$ Cell Biochem 92: 967-992.

SAKAGAMI H, AOKI J, NATORI Y, NISHIKAWA K, KAKEHI Y, NATORI Y, ARAI H (2005) Biochemical and molecular characterization of a novel choline-specific glycerophosphodiester phosphodiesterase belonging to the nucleotide pyrophosphatase/phosphodiesterase family. J Biol Chem 280: 23084-23093.

SANCHEZ T, HLA T (2004) Structural and functional characteristics of S1P receptors. J Cell Biochem 92: 913-922.

SCHLOSSER G (2006) Induction and specification of cranial placodes. Dev Biol 294: 303-351.
SENGUPTA S, WANG Z, TIPPS R, XU Y (2004) Biology of LPA in health and disease. Semin Cell Dev Bio/15: 503-512.

SHIMOMURA Y, GARZON MC, KRISTAL L, SHAPIRO L, CHRISTIANO AM (2009) Autosomal recessive woolly hair with hypotrichosis caused by a novel homozygous mutation in the P2RY5 gene. Exp Dermato/18: 218-221.

SPIEGEL S, MILSTIEN S (2003) Sphingosine-1-phosphate: an enigmatic signalling lipid. Nat Rev Mol Cell Bio/4: 397-407.

STEFAN C, JANSEN S, BOLLEN M (2005) NPP-type ectophosphodiesterases: unity in diversity. Trends Biochem Sci30: 542-550.

TABATA K, BABA K, SHIRAISHI A, ITO M, FUJITA N (2007) The orphan GPCR GPR87 was deorphanized and shown to be a lysophosphatidic acid receptor. Biochem Biophys Res Commun 363: 861-866.

TAKUWA Y, TAKUWA N, SUGIMOTO N (2002) The Edg family G protein-coupled receptors for lysophospholipids: their signaling properties and biological activities. J Biochem 131: 767-771.

THOMPSON JD, HIGGINS DG, GIBSON TJ (1994) CLUSTALW: improving the sensitivity of progressive multiple sequence alignment through sequences weighting, position-specific gap penalties and weight matrix choice. Nucleic Acids Research 22: 4673-4680.

VALENTINE WJ, FELLS JI, PERYGIN DH, MUJAHID S, YOKOYAMAK, FUJIWARA Y, TSUKAHARA R, VAN BROCKLYN JR, PARRILL AL, TIGYI G (2008) Subtype-specific residues involved in ligand activation of the endothelial differentiation gene family lysophosphatidic acid receptors. J Biol Chem283: 12175 12187

VAN MEETEREN LA, MOOLENAAR WH (2007) Regulation and biological activities of the autotaxin-LPA axis. Prog Lipid Res 46: 145-160.

WALZER T, CHIOSSONE L, CHAIX J, CALVER A, CAROZZO C, GARRIGUEANTAR L, JACQUES Y, BARATIN M, TOMASELLO E, VIVIER E (2007) Natura killer cell trafficking in vivo requires a dedicated sphingosine 1-phosphate receptor. Nat Immuno/8: 1337-1344.

WANG DA, LORINCZ Z, BAUTISTA DL, LILIOM K, TIGYI G, PARRILL AL (2001) A single amino acid determines lysophospholipid specificity of the S1P1 (EDG1) and LPA1 (EDG2) phospholipid growth factor receptors. J Biol Chem 276: 49213-49220.

WILLIAMS JR, KHANDOGA AL, GOYAL P, FELLS JI, PERYGIN DH, SIESS W, PARRILL AL, TIGYI G, FUJIWARA Y (2009) Unique Ligand Selectivity of the GPR92/LPA5 Lysophosphatidate Receptor Indicates Role in Human Platelet Activation. J Biol Chem 284: 17304-17319.

YANAGIDA K, MASAGO K, NAKANISHI H, KIHARA Y, HAMANO F, TAJIMA Y TAGUCHI R, SHIMIZU T, ISHII S (2009) Identification and characterization of a novel lysophosphatidic acid receptor, p2y5/LPA6. J Biol Chem 284: 17731 17741

YE X, HAMA K, CONTOS JJ, ANLIKER B, INOUE A, SKINNER MK, SUZUKI H, AMANO T, KENNEDY G, ARAI H, AOKI J, CHUN J (2005) LPA3-mediated lysophosphatidic acid signalling in embryo implantation and spacing. Nature 435: 104-108

ZHANG H, XU X, GAJEWIAK J, TSUKAHARA R, FUJIWARA Y, LIU J, FELLS JI, PERYGIN D, PARRILL AL, TIGYI G, PRESTWICH GD (2009) Dual activity Iysophosphatidic acid receptor pan-antagonist/autotaxin inhibitor reduces breast cancer cell migration in vitro and causes tumor regression in vivo. Cancer Res 69: 5441-5449. 


\section{Further Related Reading, published previously in the Int. J. Dev. Biol.}

See our recent Special Issue Placenta edited by Joan S. Hunt and Kent L. Thornburg at: http://www.ijdb.ehu.es/web/contents.php?vol=54\&issue=2-3

A novel role for Glucocorticoid-Induced TNF Receptor Ligand (Gitrl) in early embryonic zebrafish development Lynn D. Poulton, Kathleen F. Nolan, Corina Anastasaki, Herman Waldmann and E. Elizabeth Patton Int. J. Dev. Biol. 54: 815-825 (10.1387/ijdb.082841lp)

Ectophosphodiesterase/nucleotide phosphohydrolase (Enpp) nucleotidases: cloning, conservation and developmental restriction Karine Massé, Surinder Bhamra, Gavin Allsop, Nicholas Dale and Elizabeth A. Jones Int. J. Dev. Biol. (2010) 54: 181-193

Receptor-mediated uptake and transport of macromolecules in the human placenta Henning Schneider and Richard K. Miller Int. J. Dev. Biol. (2010) 54: 367-375

Targeted disruption of fibroblast growth factor receptor-1 blocks maturation of visceral endoderm and cavitation in mouse embryoid bodies

Milan Esner, Jiri Pachernik, Ales Hampl and Petr Dvorak

Int. J. Dev. Biol. (2002) 46: 817-825

Evolution and developmental expression of nuclear receptor genes in the ascidian Herdmania.

Christine Devine, Veronica F Hinman and Bernard M Degnan

Int. J. Dev. Biol. (2002) 46: 687-692

Sequence and translation initiation properties of the xenopus TGFbeta5, PDGF-A, and PDGF-alpha receptor 5' untranslated regions A W van der Velden, A Los, H O Voorma and A A Thomas Int. J. Dev. Biol. (2000) 44: 851-859

Retinoic acid receptors and nuclear orphan receptors in the development of Xenopus laevis $\mathrm{C}$ Dreyer and $\mathrm{H}$ Ellinger-Ziegelbauer Int. J. Dev. Biol. (1996) 40: 255-262
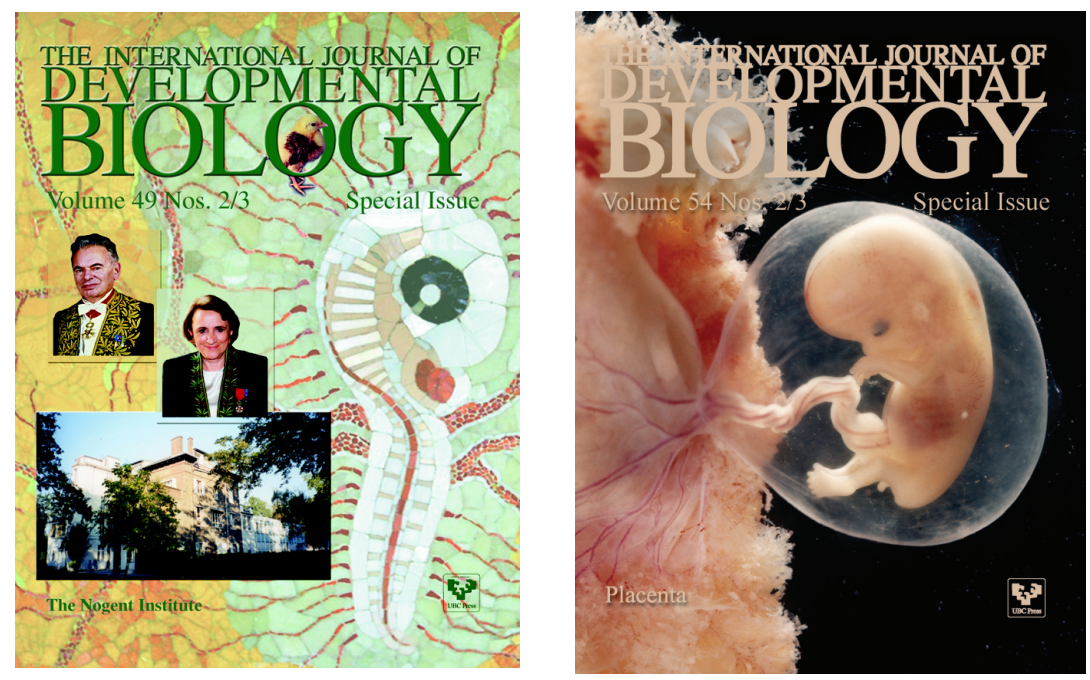

5 yr ISI Impact Factor $(2009)=3.253$

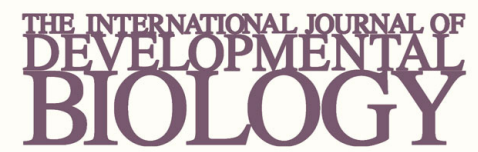

Volume 54 Nos. $6 / 7$ Special Issue

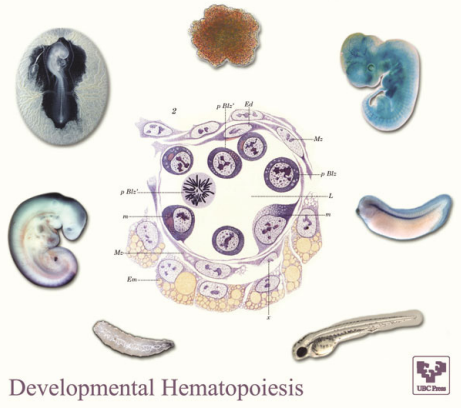

